Review

\title{
Emerging Nanopharmaceuticals and Nanonutraceuticals in Cancer Management
}

\author{
Lavinia Salama, Elizabeth R. Pastor, Tyler Stone and Shaker A. Mousa *(D) \\ The Pharmaceutical Research Institute, Albany College of Pharmacy and Health Sciences, \\ Rensselaer, NY 12144, USA; lavinia.salama@gmail.com (L.S.); elizabeth.pastor@alumni.acphs.edu (E.R.P.); \\ tyler.stone@acphs.edu (T.S.) \\ * Correspondence: shaker.mousa@acphs.edu; Tel.: +1-518-694-7397
}

Received: 4 August 2020; Accepted: 8 September 2020; Published: 12 September 2020

check for updates

\begin{abstract}
Nanotechnology is the science of nanoscale, which is the scale of nanometers or one billionth of a meter. Nanotechnology encompasses a broad range of technologies, materials, and manufacturing processes that are used to design and/or enhance many products, including medicinal products. This technology has achieved considerable progress in the oncology field in recent years. Most chemotherapeutic agents are not specific to the cancer cells they are intended to treat, and they can harm healthy cells, leading to numerous adverse effects. Due to this non-specific targeting, it is not feasible to administer high doses that may harm healthy cells. Moreover, low doses can cause cancer cells to acquire resistance, thus making them hard to kill. A solution that could potentially enhance drug targeting and delivery lies in understanding the complexity of nanotechnology. Engineering pharmaceutical and natural products into nano-products can enhance the diagnosis and treatment of cancer. Novel nano-formulations such as liposomes, polymeric micelles, dendrimers, quantum dots, nano-suspensions, and gold nanoparticles have been shown to enhance the delivery of drugs. Improved delivery of chemotherapeutic agents targets cancer cells rather than healthy cells, thereby preventing undesirable side effects and decreasing chemotherapeutic drug resistance. Nanotechnology has also revolutionized cancer diagnosis by using nanotechnology-based imaging contrast agents that can specifically target and therefore enhance tumor detection. In addition to the delivery of drugs, nanotechnology can be used to deliver nutraceuticals like phytochemicals that have multiple properties, such as antioxidant activity, that protect cells from oxidative damage and reduce the risk of cancer. There have been multiple advancements and implications for the use of nanotechnology to enhance the delivery of both pharmaceutical and nutraceutical products in cancer prevention, diagnosis, and treatment.
\end{abstract}

Keywords: dendrimers; liposomes; nanoparticles; nanopharmaceuticals; nanonutraceuticals; nanosuspension; polymeric micelles; quantum dots; solid lipid nanoparticles

\section{Introduction}

The evolution of nanoscale sciences and nanotechnology over the past two decades is responsible for the availability and growing prominence of the field of nanomedicine. Nanomedicine is a broad term to describe the use of devices or materials on the nanoscale (sizes in $\mathrm{nm}$ ) to assess, diagnose, treat, or preserve health [1]. Applying nanomedicine could include modifying how drugs are delivered in the body as a means for optimization, using imaging for various purposes, and drug tracking within the body [1,2].

With the inception of nanomedicine, the community discovered the intrinsic ability of this science to circumvent some of the most fundamental shortcomings of traditional medicine, including off-target drug side effects, non-specific cell-targeting, and drug instability. Stemming from these advancements 
are the rapidly emerging novel formulations called nanopharmaceuticals and nanonutraceuticals [2]. Nanomedicine is at the forefront of anticancer medicine, owing to the potential to limit the aforementioned shortcomings of traditional medicine. Resistance to chemotherapy has been a major challenge in treatment, due to insufficient targeting and the presence of efflux pumps (p-glycoproteins (P-gp)) in the tumor that pumps out the chemotherapeutic agents. Nanoparticles (NPs) carry medications and have the ability to overcome resistance through specific targeting of tumor cells [3]. It is important to investigate the history and current knowledge of nanopharmaceuticals and nanonutraceuticals as a means to better understand the anticancer properties that these formulations hold and their potential in moving forward.

This review covers the current repertoire of nanopharmaceuticals and nanonutraceuticals that have been approved for cancer treatment or that exhibit extensively documented anticancer properties. We also give a brief summary of common nanoformulation techniques, their application potentials and limitations, as well as some novel developments in nanoscale formulations that show promise for future growth of nanopharmaceuticals and nanonutraceuticals.

\section{Nanoformulations}

The following nanoformulations are currently being widely studied in the medical community. Each one has specific advantages and disadvantages that make them unique. They all have applicability for use in cancer treatment or diagnosis. Some nano structures are better suited for certain types of drug delivery or tumor detection over others. Additionally, each of these existing drug delivery systems have paved the way for novel nanoformulations that have come to the forefront of studies in recent years.

Various nanoplatforms are being used, from liposomes over the past two decades to metallic NPs (iron and gold) in diagnosis to polymeric and solid NPs in targeted therapeutics, as highlighted below.

\subsection{Liposomes}

Conventional liposomes are spherical amphiphilic phospholipid vesicles, approximately $25 \mathrm{~nm}-2500 \mathrm{~nm}$ in size that can protect hydrophobic or hydrophilic materials from aqueous or non-aqueous environments, respectively, by forming a closed bilayer around the material [4]. This particular feature is beneficial for the delivery of both hydrophobic and hydrophilic chemotherapy to targeted sites. For mechanisms of delivery and composition, there are five classes of liposomes that can be utilized to optimize a product's likelihood of achieving intended effects. These classes are pH-sensitive, cationic, conventional, long-circulating, and immuno-liposomes [2,5,6]. pH-sensitive liposomes stabilize when the external $\mathrm{pH}$ is altered, usually from a slightly alkaline or neutral $\mathrm{pH}$ to an acidic $\mathrm{pH}$, which makes them stable at the physiological $\mathrm{pH}$ of 7.4 [7]. However, the $\mathrm{pH}$-sensitive liposomes dissociate and release their content within the tumor, infected, or inflamed areas, which exhibit acidic properties [7]. Cationic liposomes are made using positively charged lipids and can interact with negatively-charged compounds in the body like DNA [8]. They can be used for the delivery of vaccines against cancer by loading synthetically long peptides into the liposomes to be delivered to dendritic cells, hence enhancing immune response [8]. Conventional liposomes were the first generation of liposomes and consist of a lipid bilayer. The bilayer can be neutral, cationic, or anionic phospholipids as well as cholesterol, which encompasses the aqueous volume [9]. The major disadvantage of conventional liposomes is their fast elimination from the blood. Long-circulating liposomes are generated by coupling of biocompatible polymers like polyethylene glycol (PEG) to the liposomal surface that protects the liposome from being cleared rapidly from the body [9]. Immuno-liposomes are created by attaching antibodies to the surface of the liposome. Such alteration in the liposomal structure allows for specific tissue targeting by binding to receptors specific to tumor cells [10].

Liposomal formulation is limited by its instability, poor solubility, high cost of production, and potential leakage of contained drug [4], though with recent advancements these issues are 
improving dramatically [11]. Liposomes have proven to be an efficacious and safe drug delivery system that is both biocompatible and biodegradable and does not have a risk of immunogenicity or toxicity [12]. They serve as a scaffold for carrying drugs and imaging agents, thereby increasing the circulation half-life and achieve targeting specificity. Doxorubicin HCL liposome (Doxil) is an example of a successful liposomal nano-anticancer agent used in the treatment of ovarian cancer, multiple myeloma, and AIDS-related Kaposi's sarcoma [13,14]. Doxorubicin is a hydrophilic drug that is encapsulated inside the aqueous core of a liposome. The utilization of nanomedicine to deliver doxorubicin not only prolongs the half-life and increases the concentration of doxorubicin in tumor cells, but also leads to significant reduction in adverse events like cardiotoxicity because doxorubicin as Doxil is not bioavailable to cardiac cells [13].

Liposomes can also be used for imaging and have shown potential as contrast agents for magnetic resonance imaging (MRI) in in vivo studies [15]. Liposomes can serve as a vessel to deliver MRI paramagnetic contrast agents, such as gadolinium, thus increasing contrast specificity to parts of the body that are of interest and thereby reducing systemic toxicity [16].

\subsection{Polymeric Micelles}

Polymeric micelles (PMs) are amphiphilic block copolymers with an average diameter of 10-100 nm that arrange via self-aggregation into nanoscale core-shell structures [17]. The core consists of a dense hydrophobic region and the shell consists of hydrophilic co-polymers. PMs vary in their stability in blood and in drug release rate, and they may be tweaked by the choice of chemical linkage to their surface, e.g., esters [18]. The most widely studied copolymers are poly(ester)s, poly(L-amino acid)s, and poly(propylene oxide) [19]. Having a hydrophilic surface protects them from non-specific uptake, which allows this formulation to be used for systemic delivery of hydrophobic chemotherapeutic agents [20]. Another attractive quality of PMs owing to their hydrophilic shell and nanoscopic size is that mechanical clearance of the micelles by renal filtration, reticuloendothelial system (RES) uptake, and/or by the spleen is prevented, allowing for prolonged circulation in the blood [21]. An example of a PM-formulated anticancer drug is Genexol-PM, a PM formulation of paclitaxel [22]. Paclitaxel is a poorly water-soluble chemotherapeutic agent used in the treatment of ovarian cancer, breast cancer, non-small cell lung cancer, and AIDS-related Kaposi's sarcomas [23]. In order to solubilize paclitaxel, it is often formulated in Cremophor EL (polyoxyethylated castor oil), which can lead to hypersensitivity reactions and requires pre-medication with diphenhydramine, corticosteroids, and $\mathrm{H} 2$ antagonists [23]. Genexol-PM overcomes the hypersensitivity reaction and has been approved in Korea for the treatment of advanced lung cancer and metastatic breast cancer [22].

\subsection{Dendrimers}

Dendrimers are tree-like branched-structure polymers whose shape and size are easily influenced and controlled via polymerization reactions. Branched nanostructures form around a spherical core with the ends of the dendrimers available for conjugation and molecule attachments [24,25]. Utilizing this structure permits drug and gene delivery (i.e., DNA/RNA) specificity as well as size and weight of molecule specificity, with exceptional entrapment efficiency. The high level of architectural control over dendrimers' structure makes them compelling in various settings, including chemotherapy with reduced cytotoxicity, gene therapy, immune system stimulation, increasing bioavailability, and as contrast agents for MRI [25]. Like liposomes, dendrimers can increase the solubility and bioavailability of water-insoluble agents by either encapsulating the drug/oligonucleotide in their internal cavities or attaching them though electrostatic or hydrophobic interactions to their surface [26]. Dendrimers can also serve as vehicles to transport nucleic acid-based chemotherapies, which are hydrophilic molecules that cannot easily penetrate the cell membrane [26]. 


\subsection{Quantum Dots}

Quantum dots (QDs) are semiconducting materials in nanocrystal form, 2-10 nm in size, with an inorganic core and an organic-coated shell $[27,28]$. QDs can emit fluorescence when stimulated by light. This unique characteristic of QDs makes them a useful technology in imaging and tracking of intracellular processes [29,30]. QDs can accumulate in tumor tissue, allowing for tumor visualization and non-invasive diagnosis [30]. QDs have shown promising results when studied in vitro for rapid localizations of HER-2 receptors and for targeted chemotherapy and imaging-guided therapy [31].

\subsection{Additional Novel Formulations}

Adding to the commonly used formulations discussed above, Table 1 lists additional novel formulations, their size, and a brief summary of their characteristics and application potential.

Table 1. Novel nanoformulations and their characteristics or applications in oncological medicine.

\begin{tabular}{|c|c|c|c|}
\hline Nanoformulation & Size (nm) & Characteristics/Applications & References \\
\hline Carbon nanotubes & $0.5-3$ by $20-1000$ & $\begin{array}{l}\text { Hexagonal networks of carbon that form } \\
\text { tube-like structures. Unique size, geometry, } \\
\text { and surface characteristics make these optimal } \\
\text { drug carriers for chemotherapy. } \\
\text { Studied in vitro as a potential drug delivery } \\
\text { system for controlled release of methotrexate } \\
\text { (MTX); the nano-formulated agent significantly } \\
\text { improved the antitumor function of MTX. }\end{array}$ & [32-36] \\
\hline Fullerenes & $0.7-1$ & $\begin{array}{l}\text { Carbon atoms arranged in a cage-like structure. } \\
\text { Used in imaging, drug delivery, } \\
\text { photosensitizing, and stimulating immune } \\
\text { response. Gd-metallofullerenol shown to } \\
\text { deplete breast cancer stem cells, } \\
\text { block epithelial-to-mesenchymal transition and } \\
\text { was non-toxic to healthy mammary epithelial } \\
\text { cells. Their targeted activity inhibited both } \\
\text { tumor initiation and metastasis. }\end{array}$ & [37-39] \\
\hline $\begin{array}{l}\text { Gold nanoparticles } \\
\text { (AuNP) }\end{array}$ & $1-150$ & $\begin{array}{l}\text { Can be fashioned into different shapes and sizes } \\
\text { (e.g., gold nanorods, nanospheres, nanoshells, } \\
\text { nanostars, nanocages). Unique shapes and } \\
\text { sizes make them compelling for delivery of } \\
\text { genes/oligonucleotides, proteins, and drugs to } \\
\text { specific sites of interest and for cancer } \\
\text { diagnosis and targeted phototherapy. MTX, } \\
\text { when conjugated to AuNPs, accumulates more } \\
\text { in tumor cells and at a faster rate than free } \\
\text { MTX. Doxorubicin uptake was enhanced via } \\
\text { AuNP conjugation in multi-drug resistant } \\
\text { MCF7/ADR breast cancer, enhancing toxicity } \\
\text { and overcoming drug resistance. Unique shape } \\
\text { of gold nanostar allows light absorption and } \\
\text { provides high photon-to-heat conversion } \\
\text { efficiency, making them a compelling } \\
\text { therapeutic option in tumor cell ablation. }\end{array}$ & [40-44] \\
\hline
\end{tabular}


Table 1. Cont.

\begin{tabular}{|c|c|c|c|}
\hline Nanoformulation & Size $(\mathrm{nm})$ & Characteristics/Applications & References \\
\hline $\begin{array}{l}\text { Polymer-based } \\
\text { nanoparticles }\end{array}$ & $10-1000$ & $\begin{array}{l}\text { Biodegradable polymers that are biocompatible } \\
\text { and can load both hydrophobic and } \\
\text { hydrophilic agents. Low toxicity and are } \\
\text { cheaply fabricated. Most commonly used } \\
\text { polymer is polylactic-co-glycolic acid (PLGA) } \\
\text { nanoparticle. Their architectural design may } \\
\text { affect their physiochemical properties, such as } \\
\text { efficiency of drug encapsulation, particle size, } \\
\text { distribution, stability, and shape. Introducing } \\
\text { target moieties like folic acid, biotin, antibodies, } \\
\text { and peptides to their surface that are } \\
\text { specifically recognized by tumor cell receptors } \\
\text { enhances targeting of chemotherapy. } \\
\text { Development of PLGA nanoparticles with the } \\
\text { peptide Pluronic P85, which inhibits drug } \\
\text { efflux pump, both enhances tumor suppression } \\
\text { and overcomes drug resistance. PLGA has } \\
\text { been studied with other anticancer agents like } \\
\text { mitramycin, paclitaxel, daunorubicin, } \\
\text { and doxorubicin to enhance tumor targeting. }\end{array}$ & [45-49] \\
\hline $\begin{array}{c}\text { Iron oxide } \\
\text { nanoparticles (IONP) }\end{array}$ & $1-100$ & $\begin{array}{l}\text { Type of magnetic nanoparticles (MNPs) with } \\
\text { characteristically large surface area, } \\
\text { small particle size, superparamagnetism, } \\
\text { and magnetic response. Applications in } \\
\text { diagnosis and targeted drug delivery. } \\
\text { Most common use has been as MRI contrast } \\
\text { agent to aid early detection of cancer. } \\
\text { Ferumoxil (GastroMARK) is an example of an } \\
\text { IONP that enhances MRI of gastrointestinal } \\
\text { lumen. One study suggested that IONP } \\
\text { inhibits tumor growth via induction of } \\
\text { pro-inflammatory macrophages, particularly in } \\
\text { liver cells, which accumulate high } \\
\text { concentrations of IV IONP. IONPs can provide } \\
\text { chemotherapeutic and magnetic hyperthermia } \\
\text { therapy; they act as chemotherapy drug } \\
\text { nanocarriers while generating localized heat } \\
\text { when exposed to alternating magnetic field, } \\
\text { e.g., conjugation of doxorubicin with magnetic } \\
\text { oxide nanoparticle led to a higher cell killing } \\
\text { response as a result of the alternating magnetic } \\
\text { field, leading to heat generation by } \\
\text { hyperthermia and release of doxorubicin inside } \\
\text { the tumor cell, thus showing promising results } \\
\text { in brain cancer cells treatment. }\end{array}$ & [50-56] \\
\hline Artificial exosomes & $50-120$ & $\begin{array}{l}\text { Similar to liposomes, composed of a lipid } \\
\text { bilayer and can encapsulate both hydrophobic } \\
\text { and hydrophilic drugs. Easily PEGylated to } \\
\text { enhance circulation time of a drug in blood. } \\
\text { Also engineered with various targeting ligands } \\
\text { and many proteins (like tetraspanins) that } \\
\text { provide specific organotropism. Shown to } \\
\text { improve potency and treat } \\
\text { multi-drug-resistance cancers. For example, } \\
\text { paclitaxel-encapsulated exosomes were } \\
\text { effective in vitro against human pancreatic cells } \\
\text { compared to control formulation. }\end{array}$ & [57-59] \\
\hline
\end{tabular}


Table 1. Cont.

\begin{tabular}{|c|c|c|c|}
\hline Nanoformulation & Size (nm) & Characteristics/Applications & References \\
\hline $\begin{array}{c}\text { Albumin } \\
\text { nanovectors }\end{array}$ & $5-140$ & $\begin{array}{l}\text { Biocompatible, safe, and cost-effective to } \\
\text { fabricate and can deliver both hydrophobic and } \\
\text { hydrophilic drugs and diagnostic agents. } \\
\text { Abraxane is an albumin-bound } \\
\text { nano-formulation of paclitaxel and approved } \\
\text { for the treatment of metastatic breast cancer, } \\
\text { locally advanced or metastatic lung cancer, } \\
\text { and metastatic adenocarcinoma of the pancreas. }\end{array}$ & {$[60,61]$} \\
\hline Virosomes & $\sim 150$ & $\begin{array}{l}\text { Spherical unilamellar vesicles that contain viral } \\
\text { envelopes exclusive of the viral genome that } \\
\text { serve as drug carriers in experimental cancer } \\
\text { therapies. Mostly used in vaccine development } \\
\text { like influenza (Inflexal) and hepatitis A (Epaxal) } \\
\text { vaccines. Phase } 1 \text { trial for using virosome to } \\
\text { formulate Her-2/neu multi-peptide vaccine } \\
\text { resulted in induction of anti-Her-2/neu } 2 \\
\text { specific antibodies in patients with metastatic } \\
\text { breast cancer. }\end{array}$ & {$[62,63]$} \\
\hline $\begin{array}{c}\text { Silica-based } \\
\text { nanoparticles }\end{array}$ & 20-200 & $\begin{array}{l}\text { Mesoporous silica-based nanoparticle (MSN) } \\
\text { structures can be used to load and deliver } \\
\text { antitumor agents. Well-ordered internal } \\
\text { mesopores ( 2-6 nm), large surface area, } \\
\text { modifiable size, easy surface modifications, } \\
\text { shape, and robustness make them ideal } \\
\text { nano-delivery systems. Use of MSNs for } \\
\text { doxorubicin delivery has improved the ability } \\
\text { to cross the blood-brain barrier in cell models, } \\
\text { thus making MSNs ideal for delivery of } \\
\text { antitumor agents to the brain as in } \\
\text { glioblastomas. Another example is formulation } \\
\text { of cisplatin with silica-based nanoparticles for } \\
\text { release into brain cancer cells. }\end{array}$ & [64-69] \\
\hline Nanoshells & $<100$ & $\begin{array}{l}\text { Silica core coated with metallic outer shell. } \\
\text { Properties modifiable by adjusting shell-to-core } \\
\text { ratio. Used for diagnostic, therapy, } \\
\text { immunologic. Can be contrast agents to image } \\
\text { HER2 clinical marker in breast cancer. } \\
\text { Nanoshells' exposure to HER2 or IgG } \\
\text { PEGylated antibodies facilitates targeting of } \\
\text { breast cancer cells. }\end{array}$ & [70-72] \\
\hline Nanobubbles & $40-800$ & $\begin{array}{l}\text { Bubble-like structures generated against } \\
\text { hydrophobic surfaces in liquids. Cancer drugs } \\
\text { can be incorporated and easily visualized via } \\
\text { ultrasound. Internalization of drugs to tumor } \\
\text { cells when nanobubble accumulates inside } \\
\text { tumor's interstitium due to their ability to } \\
\text { extravasate through defective tumor } \\
\text { microvasculature. Once inside, } \\
\text { nanobubble acts as a strong contrast for } \\
\text { ultrasound and once imaging is achieved, drug } \\
\text { is released from nanobubble. }\end{array}$ & [73-75] \\
\hline
\end{tabular}


Table 1. Cont.

\begin{tabular}{|c|c|c|c|}
\hline Nanoformulation & Size $(\mathrm{nm})$ & Characteristics/Applications & References \\
\hline Niosomes & $25-100$ & $\begin{array}{l}\text { Non-ionic, self-associating surfactant-based } \\
\text { vesicle in an aqueous phase. Unique delivery } \\
\text { system for both hydrophilic and lipophilic } \\
\text { drugs such as chemotherapies. Have potential } \\
\text { for targeted delivery of chemotherapy to } \\
\text { desired tumor site. Niosomal encapsulation of } \\
\text { methotrexate (MTX) and doxorubicin has } \\
\text { shown increased delivery to tumor and } \\
\text { increased tumor killing. }\end{array}$ & [76-78] \\
\hline Nanosuspensions & $<1000$ & $\begin{array}{l}\text { Fine colloid, solid pharmaceutically active } \\
\text { ingredient particles suspended and dispersed } \\
\text { in aqueous vehicles. Increases bioavailability } \\
\text { and dissolution rate of a drug. Used in in vitro } \\
\text { and in vivo studies to formulate injectable } \\
\text { sorafenib for treatment of hepatocellular } \\
\text { carcinoma. Sorafenib nanosuspension showed } \\
\text { significantly superior antitumor effect when } \\
\text { compared to oral and injectable sorafenib. }\end{array}$ & [79-82] \\
\hline
\end{tabular}

\section{Nanopharmaceuticals}

The creation of nanotechnology birthed limitless potential in many fields. Most relevant for this review is the field of nanomedicine. Specifically, in cancer therapy this technology has allowed a choice of formulations with benefits that were previously unavailable. These benefits include targeting tumor cells, initiation of apoptosis, and accumulation of drug in specific tissue for increased exposure to cancer cells. Formulation of existing pharmaceuticals into the nanoscale has decreased toxicity and increased cell specificity. Table 2 summarizes nanopharmaceuticals that have been approved for the indicated applications. The success of these nanopharmaceuticals has proven the legitimacy of this technology and its potential in the field of oncology, a field that has been particularly limited by many obstacles, such as costs of development, regulatory frameworks, applicability of test protocols, and mechanisms to test for safety/efficacy [83]. As nanomedicine has matured, there has been vast commercialization of related technology, including hardware and software that can be used to create and customize these nanoformulations with reproducible quality and quantity in modest-sized lab settings [84].

Active nano-targeting for tumor-targeted delivery could be achieved using high-affinity ligand for a unique target that is overexpressed by cancer cells and their associated microenvironment, such as the case with integrin $\alpha \mathrm{v} \beta 3$, PSMA, or CD44 for delivery of chemotherapy into specific tumors [85-91]. Nanotechnology has been studied in vitro and in vivo to potentially restrict the action of the anti-angiogenic agent, diamino tetraiodothyroacetic acid (DAT) to the integrin av $\beta 3$ by conjugating DAT to PLGA NPs, forming DAT-conjugated PLGA (NDAT). The results of the study showed that nanotechnology allows for more specific tumor targeting, thereby allowing the use of lower doses of the toxic chemotherapeutic regimens [85]. Similarly, theranostic nanocarriers (folate-HBPE (CT20p)) were studied in the delivery of therapeutic peptide (CT20p) to allow for a more selective toxicity to prostate cancer cells that express PSMA. The results of the in vivo study indicated that nanocarriers can significantly and selectively facilitate tumor reduction [86]. Similar promising results were also shown in other studies, for example in the use of docetaxel nano-targeted delivery for the treatment of prostate cancer, use of NDAT for the targeted delivery of paclitaxel, cisplatin, and doxorubicin in tumor xenografts and in the delivery of toremifene in prostate cancer [87-91]. 
Table 2. Approved oncological nanopharmaceuticals and their applications.

\begin{tabular}{|c|c|c|c|c|c|}
\hline Product & Drug & Formulation & Company & ROA & Application (Approval Year) \\
\hline DaunoXome & Daunorubicin Citrate & Liposome & Galen & IV & Kaposi Sarcoma (1996) \\
\hline DepoCyt & Cytarabine & Liposome & Pacira & IT & Neoplastic and Lymphomatous Meningitis (1999) \\
\hline Doxil & Doxorubicin $\mathrm{HCl}$ & Liposome & Janssen & IV & Kaposi Sarcoma, Ovarian cancer, Multiple myeloma (1995) \\
\hline Marqibo & Vincristine Sulfate & Liposome & Spectrum & IV & Acute Lymphoid Leukemia (2012) \\
\hline Mepact & Mifamurtide & Liposome & Takeda & IV & High-grade Non-metastatic Osteosarcoma (EU 2009) \\
\hline Myocet & Doxorubicin & Liposome & Teva & IV & Metastatic Breast Cancer (EU 2000) \\
\hline Neulasta & Filgrastim & PEGylated protein & Amgen & SC & Febrile Neutropenia, in Non-myeloid Malignancies (2002) \\
\hline Oncaspar & Pegaspargase & PEGylated protein & Shire & $\mathrm{IM} / \mathrm{IV}$ & Acute Lymphoblastic Leukemia (1994) \\
\hline Eligard & Leuprolide Acetate & Polymer-based & Tolmar & SC & Advanced Prostate Cancer (2002) \\
\hline Genexol & Paclitaxel & Polymer-based & Samyang & IV & Pancreatic Cancer, Metastatic Breast Cancer (SK 2001) \\
\hline Opaxio & Paclitaxel & Polymer-based & CTI Biopharma & IV & Glioblastoma, NSC Lung Cancer, Ovarian cancer (pending) \\
\hline Zinostatin stimalamer & $\begin{array}{l}\text { Styrenemaleic acid and } \\
\text { NCS protein }\end{array}$ & Polymer-based & Astellas & IV & Hepatoma (JP 1994) \\
\hline Abraxane & Albumin and paclitaxel & Protein-drug conj. & Celgene & IV & $\begin{array}{c}\text { Metastatic Breast Cancer, NSC Lung Cancer, Metastatic } \\
\text { Adenocarcinoma of the Pancreas (2005) }\end{array}$ \\
\hline Kadcyla & Trastuzumab emtansine & Protein-drug conj. & Genentech & IV & Metastatic Breast Cancer (2013) \\
\hline Ontak & Denileukin diftitox & Protein-drug conj. & Eisai & IV & Persistent or Recurrent Cutaneous T-cell Lymphoma (1999) \\
\hline NanoTherm & Iron oxide+aminosilane & Metal-based & MagForce & ITU & Prostate cancer, Pancreatic cancer, Glioblastoma (EU 2013) \\
\hline Gendicine & rAd-p53 & Virosome & Shenzhen & ITU & Head and Neck Squamous Cell Carcinoma (CN 2003) \\
\hline Rexin-G & Cyclin G1 inhibitor & Virosome & Epeius & IV & Solid Tumors (PH 2007) \\
\hline
\end{tabular}

ROA, route of administration; IV, intravenous; IT, intrathecal; SC, subcutaneous; IM, intramuscular; ITU, intratumorally; PEG, polyethylene glycol; Two letters before year notates approval in specific countries/regions; EU, Europe; SK, South Korea; JP, Japan; CN, Canada; PH, Philippines; all others approved in the United States. 


\section{Nanonutraceuticals}

Nutraceuticals are typically defined as pharmaceutical-grade standardized nutrients derived from food sources that, in addition to providing basic nutrients, also provide extra health benefits [92]. They mainly differ from non-pharmaceuticals in that they do not provide a pharmacologically active ingredient and instead deliver nutritional supplementation for medicinal purposes [93]. There has been widespread growth in the use of phytochemicals in nutraceuticals [94].

Phytochemicals are the naturally occurring chemicals in many plants that exhibit biologically active characteristics, including plant growth or defense. Many of these phytochemicals have been studied for centuries for their wide-ranging effects and medicinal value [94]. Phytochemicals like flavonoids suppress oxidative stress-induced DNA damage, primarily through their antioxidant properties, and thus they play a role in cancer chemoprevention $[95,96]$. Another example is the use of indoles found in cabbage that reduce the effects of estrogen and hence reduce the risk of developing breast cancer [97]. Capsaicin, found in chili pepper, is believed to protect DNA from carcinogens [98]. Formulating these nutraceuticals on the nanoscale, similarly to nanopharmaceuticals, may allow more pronounced and targeted effects that were previously unachievable.

Nutraceuticals derived from phytochemicals that have been studied for their potential anticancer properties exhibit promising results. Table 3 is a comprehensive list of phytochemicals that have been nano-formulated and studied in the corresponding cancer models. Moving forward, this subgroup of nanomedicine has great potential for growth because the major limiting characteristics of nutraceuticals, such as poor bioavailability and limited absorption in the gastrointestinal tract, can be overcome [99]. As the trend of seeking natural alternatives for prescription medications continues to grow, the younger, less-explored field of nanonutraceuticals may prove to be the lowest hanging fruit of all.

Table 3. Phytochemicals and their application in nanomedicine.

\begin{tabular}{|c|c|c|}
\hline Phytochemical & Application/Targets & Delivery System \\
\hline$\beta$-Lapachone & $\begin{array}{l}\text { Colon cancer cells, lung [100], prostate, } \\
\text { breast cancer cells [101] }\end{array}$ & PEG-PLA polymer micelles $[102,103]$ \\
\hline Curcumin & $\begin{array}{l}\text { Brain [104], leukemia, colon [105], } \\
\text { breast [106], prostate [107], } \\
\text { cervical [108-110], pancreatic cancer } \\
\text { cells [111], neuroblastoma [112] }\end{array}$ & $\begin{array}{l}\text { PLGA, PLA-vitamin E TPGS copolymer, } \\
\text { alginate NPs, soy protein NPs, } \\
\text { PVP conjugate micelle, } \alpha \text {-CD derivatives, } \\
\text { thermosensitive polymer NP, } \\
\text { nanoprecipitation, liposomal formulation, } \\
\text { magnetic NP, hollow capsules, } \\
\text { albumin nanosuspension }[113,114]\end{array}$ \\
\hline Daidzein & $\begin{array}{l}\text { Cardiovascular system [115], } \\
\text { breast cancer [116] }\end{array}$ & SLN with PEGylated phospholipid \\
\hline Dibenzoylmethane & $\begin{array}{l}\text { Cervical cancer cells, hepatic cancer, } \\
\text { prostate cancer, lung cancer, } \\
\text { osteosarcoma [117-119] }\end{array}$ & PLA NP \\
\hline Dihydroartemisinin & $\begin{array}{l}\text { Breast cancer [120], ovarian cancer [121], } \\
\text { esophageal cancer [122] }\end{array}$ & Magnetic NP \\
\hline Ellagic acid & $\begin{array}{l}\text { Breast cancer [123], prostate cancer, } \\
\text { colorectal cancer, melanoma, } \\
\text { ovarian cancer, non-small cell lung cancer } \\
\text { (NSCLC), bladder cancer }[124,125]\end{array}$ & PLGA NP, PEG, mesoporous silica NP \\
\hline $\begin{array}{l}\text { Epigallocatechin Gallate } \\
\text { (EGCG) }\end{array}$ & $\begin{array}{l}\text { Prostate cancer cells, pancreatic cancer } \\
\text { cells [126], breast cancer [127], } \\
\text { ovarian cancer, endometrial cancer, } \\
\text { renal cancer, and colon cancer }\end{array}$ & $\begin{array}{l}\text { Lipid NP, polymeric NP (PLA and PLGA), } \\
\text { liposomes, gold NP, selenium } \\
\text { nanocarriers, PEG [128] }\end{array}$ \\
\hline Eugenol & $\begin{array}{l}\text { Colon and liver cancer [129], } \\
\text { breast cancer }[130,131]\end{array}$ & Nanoemulsions, magnetic NP \\
\hline
\end{tabular}


Table 3. Cont.

\begin{tabular}{|c|c|c|}
\hline Phytochemical & Application/Targets & Delivery System \\
\hline Ferulic acid & $\begin{array}{l}\text { Hepatocellular cancer, colon cancer [132], } \\
\text { pancreatic cancer [133] }\end{array}$ & NP, chitosan-coated SLN \\
\hline Gambogic acid & Breast cancer, pancreatic cancer [134] & $\begin{array}{l}\text { Glycol chitosan NP, NP coated with red } \\
\text { blood cell membranes [135], } \\
\text { carbo nanotube and graphene } \\
\text { nanodelivery, magnetic NPs }\end{array}$ \\
\hline Genistein & $\begin{array}{l}\text { Breast cancer, prostate cancer, } \\
\text { colon cancer [136], osteosarcoma, human } \\
\text { gastric carcinoma, neuroblastoma, } \\
\text { bladder cancer, lung cancer, } \\
\text { cervical cancer [137] }\end{array}$ & $\begin{array}{l}\text { Biodegradable TPGS-b-PCL NP, } \\
\text { PEGylated silica NP, hybrid nanomaterial }\end{array}$ \\
\hline Honokiol & $\begin{array}{l}\text { Liver cancer [138], breast cancer [139], } \\
\text { colorectal cancer [140], lymphoid } \\
\text { malignant cells [141], melanoma [142], } \\
\text { thyroid cancer [143], glioblastoma [144] }\end{array}$ & $\mathrm{NP}$, nanosome, QD \\
\hline Naringenin & $\begin{array}{l}\text { Cervical cancer [145], glioblastoma, } \\
\text { lung cancer [146], pancreatic cancer [147] }\end{array}$ & $\begin{array}{l}\text { Silk fibroin NP, naringenin loaded PCL } \\
\text { NP, multi-walled carbon nanotubes, } \\
\text { naringenin-loaded PLGA NP }\end{array}$ \\
\hline Nobiletin & $\begin{array}{l}\text { Breast cancer, ovarian cancer, } \\
\text { prostate cancer, colon cancer [148], } \\
\text { liver cancer, hepatocellular carcinomas, } \\
\text { glioblastoma, gastric cancer, lung cancer, } \\
\text { nasopharyngeal cancer [149] }\end{array}$ & Nano-emulsion [150], micelles \\
\hline Quercetin & $\begin{array}{l}\text { Breast cancer [151], } \\
\text { ovarian cancer [152,153], cervical cancer, } \\
\text { prostate cancer, colorectal cancer, } \\
\text { gastrointestinal cancer, liver cancer [154], } \\
\text { thyroid cancer, lung cancer, } \\
\text { pancreatic cancer, lymphomas }\end{array}$ & $\begin{array}{l}\text { Quercetin encapsulated in SLN [155], } \\
\text { gold NP-quercetin into PLGA, graphene } \\
\text { oxide nanocarrier }\end{array}$ \\
\hline Resveratrol & $\begin{array}{l}\text { Skin cancer, breast cancer, prostate cancer, } \\
\text { pancreatic cancer }\end{array}$ & Gold NP [156], SLN [157] \\
\hline Thymoquinone & $\begin{array}{l}\text { Glioblastoma [158], breast cancer, } \\
\text { ovarian cancer, osteosarcoma, } \\
\text { colorectal cancer, adenocarcinoma, } \\
\text { pancreatic carcinoma, myeloblastic } \\
\text { leukemia }[159,160]\end{array}$ & $\begin{array}{l}\text { Silica NP core loaded with thymoquinone, } \\
\text { thymoquinone-loaded nanostructured } \\
\text { lipid carriers, PLGA and PEG, } \\
\text { thymoquinone-encapsulated chitosan NP, } \\
\text { 1,2-dipalmitoyl-sn-glycerol-3-phosphocholine } \\
\text { liposomal system, micelles }\end{array}$ \\
\hline Triptolide & $\begin{array}{l}\text { Breast cancer [161], liver cancer, } \\
\text { lung cancer, pancreatic cancer }[162,163]\end{array}$ & $\begin{array}{l}\text { Triptolide-loaded cationic liposomes, } \\
\text { triptolide coupled to vitamin E using } \\
\text { dithiodiglycolic acid and co-dissolved } \\
\text { with PEG2000-linoleic acid, } \\
\text { nucleolin-specific aptamer mediated } \\
\text { polymeric nanocarrier }\end{array}$ \\
\hline Taxifolin & $\begin{array}{l}\text { Colorectal cancer, } \\
\text { breast cancer }[164][165,166]\end{array}$ & $\begin{array}{l}\text { Zinc oxide NP, NP by liquid } \\
\text { antisolvent precipitation }\end{array}$ \\
\hline Ursolic acid & $\begin{array}{l}\text { Cervical cancer [167], breast cancer [168], } \\
\text { prostate cancer, lung cancer, } \\
\text { hepatocellular carcinoma [169], gall } \\
\text { bladder carcinoma, melanoma [170] }\end{array}$ & $\begin{array}{l}\text { Gold-ursolic acid into PLGA NP, } \\
\text { long-circulating and pH-sensitive } \\
\text { liposomes [171], PEG modified } \\
\text { liposome [172], ursolic acid-loaded } \\
\text { chitosan NP [173], pH-sensitive } \\
\text { mesoporous silica NP }\end{array}$ \\
\hline
\end{tabular}

CD, cyclodextrin; NP, nanoparticle; PCL, polycaprolactone; PEG, polyethylene glycol; PLA, poly(lactide); PLGA, poly lactic-co-glycolic acid; PVP, poly(vinyl pyrrolidone); QD, quantum dot; SLN, solid lipid NP; TPGS, tocopheryl polyethylene glycol 1000 succinate. 
The physicochemical properties of phytochemicals such as polyphenols, phytosterols, carotenoids, vitamins, and minerals have a number of limitations, such as solubility, stability, and permeability, which could be improved using biodegradable nano assembly systems such as PLGA, chitosan, and natural fatty acids. Nanoformulation of natural bioactive compounds or natural extracts has demonstrated improved bio-accessibility/bioavailability. Different nanonutraceuticals demonstrated improved pharmacokinetic and pharmacodynamic properties that could facilitate their transition into pharmaceuticals and nanopharmaceuticals [125,174-178].

\section{The Promising Future for Oncology with Nanomedicine}

There are innumerable limitations when it comes to oncologic therapy. Most often cited is the lack of targeting and cell specification that leads to exaggerated negative side effects. These side effects are typically detrimental to patients' health and can have a significant impact on quality of life. Using nanotechnology with enhanced tumor targeting capabilities may significantly save patients from immense pain and suffering and will combat multi-drug resistance and enhance tumor killing [179].

Nanotechnology has much potential in that it could be used for cancer diagnosis, treatment, and potentially the development of vaccines. Nanotechnology allows for more sensitive diagnosis of cancer by targeting specific cancer biomarkers, such as exosomes, cancer-associated proteins, circulating tumor DNA, and tumor cells [180]. Nanotechnology has been extensively studied in laboratory settings, however clinical data are often lacking. There are multiple ongoing trials looking at the use of nanotechnology in increasing the sensitivity and specificity of cancer diagnosis. A phase 1 trial is currently evaluating the use of ultrasmall silica particle in brain tumor imaging in humans [181]. This is the first human trial evaluating silica NPs in brain cancers. Understanding the mechanisms of distribution and excretion of the silica NPs in humans would be beneficial in future targeted oncological therapies. Carbon NPs are being studied as lymph node tracers in colorectal cancers to assess whether carbon NPs can increase lymph node yield after surgery [182]. Ferumoxytol-iron oxide NPs magnetic resonance is being evaluated as a potential tool to gain insights about the spread of cancers [183]. Another study evaluated the use of nanosensors in the diagnosis of gastric diseases [184]. Nanochip technology is also being studied as a potential tool for monitoring treatment response and detection of relapse in patients with diffuse large B-cell lymphomas [185]. As clinical research continues, we will see nanotechnology flourish in the field of oncology to aid in diagnosis and treatment.

\section{Challenges and Promises in the Advancement of Nanoproducts (Nanomedicine)}

Challenges facing the delivery of NPs carrying anticancer drugs to solid tumors include tumor microenvironments, matrix barriers such as fibrosis, collagen, and other matrices, tumor heterogeneity with variable vasculature, and the poorly vascularized tumor core. Current research in NP-based tumor drug delivery is focused on "active" targeting of NPs to the target rather than the traditional "passive" targeting through the enhanced permeability and retention (EPR) system.

Nonpharmaceutical formulations have distinct challenges from conventional pharmaceutical products that make their development more challenging. Cost of production of nanopharmaceuticals poses an important challenge. Nanopharmaceuticals are highly complex molecules that require careful selection of shape, vehicles, inorganic materials, and optimization of pharmacokinetic parameters to meet therapeutic needs and proper storage. Large-scale production of nanotherapeutics require high-efficiency equipment, time, and space. The higher the complexity of the desired nonpharmaceutical, the higher the cost of production and cost of acquisition. The cost-effectiveness of developing nanopharmaceuticals/nanonutraceuticals must be taken into consideration [186,187]. To justify their cost of production, a carefully planned and well-designed manufacturing process is going to be essential [188]. If careful manufacturing planning is not completed, reliability of nanotechnology in cancer diagnosis and treatment may be compromised. For example, there are various factors that affect the NP detection signaling and thus the sensitivity and specificity of cancer detection [189]. 
Manufacturing might not be an issue for all approved products that were aimed at passive targeting, but it might represent a challenge for active nano-targeting where there is a need to chemically conjugate the targeting moiety (small molecule, antibody, or aptamer) to the nanoplatform and then load the drugs to be delivered into the tumor and its microenvironment. However, those challenges can also be overcome. An example of such success is the case with BIND-014, a PSMA-targeted ACCURIN containing docetaxel, in patients with chemotherapy-naive metastatic castration-resistant prostate cancer. BIND-014 was clinically active and well-tolerated and the study met its primary endpoint, with $71 \%$ of patients achieving relative progression-free survival of at least six months. Unfortunately, the success rate for phase 3 trials was a mere $~ 14 \%$, with failures stemming from lack of efficacy $[190,191]$.

Physiochemical properties of the NPs such as shape, size, surface charges, surface ligands, absorption, distribution, metabolization, and excretion play a role in potential toxicity in the human body. Moreover, long-term toxicity from prolonged NP exposure (e.g., from nano-based imaging and treatment) cannot be fully and quickly known from in vivo studies [188].

Another important challenge to consider is FDA regulation of nanopharmaceuticals/ nanonutraceuticals. Currently, the FDA approach to reviewing nanopharmaceuticals is the same as products that do not contain nanomaterials. Complexity and diversity of nano formulations is increasing significantly and thus the regulatory structure set forth by the FDA seems inadequate. Challenges involving safety, efficacy, and proper labeling are likely to arise $[188,192,193]$.

Despite these challenges, nano-delivery of approved or new novel anticancer mechanisms holds great promise in the improved management of cancer and other disorders [194-198]. Nanoparticle-based drug delivery improves efficacy, solubility of hydrophobic drugs, half-lives of unstable compounds and proteins, and allows controlled and targeted release of drugs at the tumor site and its microenvironment. Ultimately, the integration of various enabling technologies and cross-collaboration with multidisciplinary theoretical and experimental scientists across academia and the pharmaceutical industry will accelerate these developments from the bench to the bedside and eventually to the market. Effective and safe cancer management continues to be a major issue in achieving improved survival and quality of life, because most anticancer drugs are cytotoxic and have a narrow therapeutic index.

\section{Moving Forward Toward the Adaption of Nanomedicine toward Precision Medicine}

Several nanopharmaceutical products in cancer and non-cancer indications are progressing at various stages of clinical development with great promises to improve the efficacy and safety of existing or new and novel compounds [199]. Clearly nanomedicine has provided recent success in drug delivery and tumor targetability that will increase the adaption of nanoproducts in cancer and beyond in the upcoming 2020-2030 decade. Nano-targeted delivery of active pharmaceuticals or biopharmaceuticals into the tumor site and its microenvironment should improve efficacy and safety as well as bypass hepatic pharmacogenomic variability in drug metabolism, allowing for better precision medicines in cancer and beyond.

\section{Conclusions}

The once hypothetical visions of what nanotechnology had to offer nanomedicine, specifically in the subgroups of nanopharmaceuticals and nanonutraceuticals, are now becoming reality. With the extensive investments that have been put into nanomedicine over the past two decades, there have been groundbreaking discoveries that paved the way to the approvals of many nanopharmaceuticals, with many more currently in process. In recent years, billions of dollars have been fronted to create academic institutes dedicated to the study of nanotechnology, and thus scientists are flocking to the field, with many dedicated to the study of nanomedicine. As nanomedicine continues to prove its value and legitimacy, nanoformulations of pharmaceuticals and nutraceuticals should continue to grow prolifically. Oncology, in particular, has many obstacles to overcome, because current treatment 
options are less than ideal. Thus, the options for oncology therapeutics are just beginning to propagate as the gold rush to nanomedicine matures. It is, however, important to remember that although nanotechnology holds great potential, it may not be the answer to curing all cancers.

Funding: This research received no external funding.

Conflicts of Interest: S.A.M. holds stock in NanoPharmaceuticals LLC, which is developing anticancer drugs. All other authors declare no competing financial interest.

\section{References}

1. Saini, R.; Saini, S.; Sharma, S. Nanotechnology: The future medicine. J. Cutan. Aesthetic Surg. 2010, 3, 32-33. [CrossRef]

2. Perez-Herrero, E.; Fernandez-Medarde, A. Advanced targeted therapies in cancer: Drug nanocarriers, the future of chemotherapy. Eur. J. Pharm. Biopharm. 2015, 93, 52-79. [CrossRef]

3. Zhang, M.; Liu, E.; Cui, Y.; Huang, Y. Nanotechnology-based combination therapy for overcoming multidrug-resistant cancer. Cancer Biol. Med. 2017, 14, 212-227. [CrossRef] [PubMed]

4. Akbarzadeh, A.; Rezaei-Sadabady, R.; Davaran, S.; Joo, S.W.; Zarghami, N.; Hanifehpour, Y.; Samiei, M.; Kouhi, M.; Nejati-Koshki, K. Liposome: Classification, preparation, and applications. Nanoscale Res. Lett. 2013, 8, 102. [CrossRef] [PubMed]

5. Paliwal, S.R.; Paliwal, R.; Vyas, S.P. A review of mechanistic insight and application of $\mathrm{pH}$-sensitive liposomes in drug delivery. Drug Deliv. 2015, 22, 231-242. [CrossRef] [PubMed]

6. Shim, G.; Kim, M.-G.; Park, J.Y.; Oh, Y.-K. Application of cationic liposomes for delivery of nucleic acids. Asian J. Pharm. Sci. 2013, 8, 72-80. [CrossRef]

7. Karanth, H.; Murthy, R.S. pH-sensitive liposomes-principle and application in cancer therapy. J. Pharm. Pharmacol. 2007, 59, 469-483. [CrossRef] [PubMed]

8. Heuts, J.; Varypataki, E.M.; van der Maaden, K.; Romeijn, S.; Drijfhout, J.W.; van Scheltinga, A.T.; Ossendorp, F.; Jiskoot, W. Cationic liposomes: A flexible vaccine delivery system for physicochemically diverse antigenic peptides. Pharm. Res. 2018, 35, 207. [CrossRef]

9. Sercombe, L.; Veerati, T.; Moheimani, F.; Wu, S.Y.; Sood, A.K.; Hua, S. Advances and challenges of liposome assisted drug delivery. Front. Pharmacol. 2015, 6, 286. [CrossRef]

10. Paszko, E.; Senge, M.O. Immunoliposomes. Curr. Med. Chem. 2012, 19, 5239-5277. [CrossRef]

11. Alavi, M.; Karimi, N.; Safaei, M. Application of various types of liposomes in drug delivery systems. Adv. Pharm. Bull. 2017, 7, 3-9. [CrossRef] [PubMed]

12. Lungu, I.I.; Grumezescu, A.M.; Volceanov, A.; Andronescu, E. Nanobiomaterials used in cancer therapy: An up-to-date overview. Molecules 2019, 24, 3547. [CrossRef] [PubMed]

13. Bulbake, U.; Doppalapudi, S.; Kommineni, N.; Khan, W. Liposomal formulations in clinical use: An updated review. Pharmaceutics 2017, 9, 12. [CrossRef] [PubMed]

14. Doxil Package Insert. Available online: http://www.janssenlabels.com/package-insert/product-monograph/ prescribing-information/DOXIL-pi.pdf (accessed on 2 January 2020).

15. German, S.V.; Navolokin, N.A.; Kuznetsova, N.R.; Zuev, V.V.; Inozemtseva, O.A.; Anis'kov, A.A.; Volkova, E.K.; Bucharskaya, A.B.; Maslyakova, G.N.; Fakhrullin, R.F.; et al. Liposomes loaded with hydrophilic magnetite nanoparticles: Preparation and application as contrast agents for magnetic resonance imaging. Colloids Surf. B Biointerfaces 2015, 135, 109-115. [CrossRef]

16. Pellico, J.; Ellis, C.M.; Davis, J.J. Nanoparticle-based paramagnetic contrast agents for magnetic resonance imaging. Contrast Media Mol. Imaging 2019, 2019, 1845637. [CrossRef]

17. Deshantri, A.K.; Varela Moreira, A.; Ecker, V.; Mandhane, S.N.; Schiffelers, R.M.; Buchner, M.; Fens, M. Nanomedicines for the treatment of hematological malignancies. J. Control. Release 2018, 287, 194-215. [CrossRef]

18. Shin, D.H.; Tam, Y.T.; Kwon, G.S. Polymeric micelle nanocarriers in cancer research. Front. Chem. Sci. Eng. 2016, 10, 348-359. [CrossRef]

19. Croy, S.R.; Kwon, G.S. Polymeric micelles for drug delivery. Curr. Pharm. Des. 2006, 12, 4669-4684. [CrossRef]

20. Cho, H.; Lai, T.C.; Tomoda, K.; Kwon, G.S. Polymeric micelles for multi-drug delivery in cancer. AAPS PharmSciTech 2015, 16, 10-20. [CrossRef] 
21. Kulthe, S.S.; Choudhari, Y.M.; Inamdar, N.N.; Mourya, V. Polymeric micelles: Authoritative aspects for drug delivery. Des. Monomers Polym. 2012, 15, 465-521. [CrossRef]

22. Ventola, C.L. Progress in nanomedicine: Approved and investigational nanodrugs. Pharm. Ther. 2017, 42, 742-755.

23. Taxol@(Paclitaxel) Injection Package Insert. Available online: https://www.accessdata.fda.gov/drugsatfda docs/label/2011/020262s0491bl.pdf (accessed on 2 January 2020).

24. Castro, R.I.; Forero-Doria, O.; Guzman, L. Perspectives of dendrimer-based nanoparticles in cancer therapy. An. Acad. Bras. Cienc. 2018, 90, 2331-2346. [CrossRef] [PubMed]

25. Abbasi, E.; Aval, S.F.; Akbarzadeh, A.; Milani, M.; Nasrabadi, H.T.; Joo, S.W.; Hanifehpour, Y.; Nejati-Koshki, K.; Pashaei-Asl, R. Dendrimers: Synthesis, applications, and properties. Nanoscale Res. Lett. 2014, 9, 247. [CrossRef] [PubMed]

26. Palmerston Mendes, L.; Pan, J.; Torchilin, V.P. Dendrimers as nanocarriers for nucleic acid and drug delivery in cancer therapy. Molecules (Basel Switz.) 2017, 22, 1401. [CrossRef]

27. Cuenca, A.G.; Jiang, H.; Hochwald, S.N.; Delano, M.; Cance, W.G.; Grobmyer, S.R. Emerging implications of nanotechnology on cancer diagnostics and therapeutics. Cancer 2006, 107, 459-466. [CrossRef]

28. Fang, M.; Peng, C.W.; Pang, D.W.; Li, Y. Quantum dots for cancer research: Current status, remaining issues, and future perspectives. Cancer Biol. Med. 2012, 9, 151-163.

29. Pisanic, T.R., II; Zhang, Y.; Wang, T.H. Quantum dots in diagnostics and detection: Principles and paradigms. Analyst 2014, 139, 2968-2981. [CrossRef]

30. Zdobnova, T.A.; Lebedenko, E.N.; Deyev, S.M. Quantum dots for molecular diagnostics of tumors. Acta Nat. 2011, 3, 29-47. [CrossRef]

31. Rizvi, S.B.; Rouhi, S.; Taniguchi, S.; Yang, S.Y.; Green, M.; Keshtgar, M.; Seifalian, A.M. Near-infrared quantum dots for HER2 localization and imaging of cancer cells. Int. J. Nanomed. 2014, 9, 1323-1337.

32. Sinha, N.; Yeow, J.T. Carbon nanotubes for biomedical applications. IEEE Trans. Nanobioscience 2005, 4, 180-195. [CrossRef]

33. Reilly, R.M. Carbon nanotubes: Potential benefits and risks of nanotechnology in nuclear medicine. J. Nucl. Med. 2007, 48, 1039-1042. [CrossRef] [PubMed]

34. Prato, M.; Kostarelos, K.; Bianco, A. Functionalized carbon nanotubes in drug design and discovery. Acc. Chem. Res. 2008, 41, 60-68. [CrossRef] [PubMed]

35. Saeednia, L.; Yao, L.; Cluff, K.; Asmatulu, R. Sustained releasing of methotrexate from injectable and thermosensitive chitosan-carbon nanotube hybrid hydrogels effectively controls tumor cell growth. ACS Omega 2019, 4, 4040-4048. [CrossRef] [PubMed]

36. Dong, J.; Ma, Q. Integration of inflammation, fibrosis, and cancer induced by carbon nanotubes. Nanotoxicology 2019, 13, 1244-1274. [CrossRef] [PubMed]

37. Bakry, R.; Vallant, R.M.; Najam-ul-Haq, M.; Rainer, M.; Szabo, Z.; Huck, C.W.; Bonn, G.K. Medicinal applications of fullerenes. Int. J. Nanomed. 2007, 2, 639-649.

38. Bogdanovic, G.; Djordjevic, A. Carbon nanomaterials: Biologically active fullerene derivatives. Srp. Arh. Celok. Lek. 2016, 144, 222-231. [CrossRef]

39. Liu, Y.; Chen, C.; Qian, P.; Lu, X.; Sun, B.; Zhang, X.; Wang, L.; Gao, X.; Li, H.; Chen, Z.; et al. Gd-metallofullerenol nanomaterial as non-toxic breast cancer stem cell-specific inhibitor. Nat. Commun. 2015, 6, 5988. [CrossRef]

40. Singh, P.; Pandit, S.; Mokkapati, V.R.S.S.; Garg, A.; Ravikumar, V.; Mijakovic, I. Gold nanoparticles in diagnostics and therapeutics for human cancer. Int. J. Mol. Sci. 2018, 19, 1979. [CrossRef]

41. Surendran, S.P.; Moon, M.J.; Park, R.; Jeong, Y.Y. Bioactive nanoparticles for cancer immunotherapy. Int. J. Mol. Sci. 2018, 19, 3877. [CrossRef]

42. Khademi, S.; Sarkar, S.; Shakeri-Zadeh, A.; Attaran, N.; Kharrazi, S.; Ay, M.R.; Azimian, H.; Ghadiri, H. Targeted gold nanoparticles enable molecular CT imaging of head and neck cancer: An in vivo study. Int. J. Biochem. Cell Biol. 2019, 114, 105554. [CrossRef]

43. Liu, Y.; Crawford, B.M.; Vo-Dinh, T. Gold nanoparticles-mediated photothermal therapy and immunotherapy. Immunotherapy 2018, 10, 1175-1188. [CrossRef] [PubMed]

44. Sztandera, K.; Gorzkiewicz, M.; Klajnert-Maculewicz, B. Gold nanoparticles in cancer treatment. Mol. Pharm. 2019, 16, 1-23. [CrossRef] [PubMed] 
45. Huang, W.; Zhang, C. Tuning the size of poly(lactic-co-glycolic acid) (PLGA) nanoparticles fabricated by nanoprecipitation. Biotechnol. J. 2018, 13. [CrossRef] [PubMed]

46. Kim, K.-T.; Lee, J.-Y.; Kim, D.-D.; Yoon, I.-S.; Cho, H.-J. Recent progress in the development of poly(lactic-co-glycolic acid)-based nanostructures for cancer imaging and therapy. Pharmaceutics 2019, 11, 280. [CrossRef] [PubMed]

47. Chen, Y.; Li, N.; Xu, B.; Wu, M.; Yan, X.; Zhong, L.; Cai, H.; Wang, T.; Wang, Q.; Long, F.; et al. Polymer-based nanoparticles for chemo/gene-therapy: Evaluation its therapeutic efficacy and toxicity against colorectal carcinoma. Biomed. Pharmacother. 2019, 118, 109257. [CrossRef] [PubMed]

48. Mukherjee, A.; Waters, A.K.; Kalyan, P.; Achrol, A.S.; Kesari, S.; Yenugonda, V.M. Lipid-polymer hybrid nanoparticles as a next-generation drug delivery platform: State of the art, emerging technologies, and perspectives. Int. J. Nanomed. 2019, 14, 1937-1952. [CrossRef]

49. Widmer, J.; Thauvin, C.; Mottas, I.; Nguyen, V.N.; Delie, F.; Allémann, E.; Bourquin, C. Polymer-based nanoparticles loaded with a TLR7 ligand to target the lymph node for immunostimulation. Int. J. Pharm. 2018, 535, 444-451. [CrossRef]

50. Wu, M.; Huang, S. Magnetic nanoparticles in cancer diagnosis, drug delivery and treatment. Mol. Clin. Oncol. 2017, 7, 738-746. [CrossRef]

51. Zanganeh, S.; Hutter, G.; Spitler, R.; Lenkov, O.; Mahmoudi, M.; Shaw, A.; Pajarinen, J.S.; Nejadnik, H.; Goodman, S.; Moseley, M.; et al. Iron oxide nanoparticles inhibit tumour growth by inducing pro-inflammatory macrophage polarization in tumour tissues. Nat. Nanotechnol. 2016, 11, 986-994. [CrossRef]

52. Carvalho, S.M.; Leonel, A.G.; Mansur, A.A.P.; Carvalho, I.C.; Krambrock, K.; Mansur, H.S. Bifunctional magnetopolymersomes of iron oxide nanoparticles and carboxymethylcellulose conjugated with doxorubicin for hyperthermo-chemotherapy of brain cancer cells. Biomater. Sci. 2019, 7, 2102-2122. [CrossRef]

53. Lugert, S.; Unterweger, H.; Mühlberger, M.; Janko, C.; Draack, S.; Ludwig, F.; Eberbeck, D.; Alexiou, C.; Friedrich, R.P. Cellular effects of paclitaxel-loaded iron oxide nanoparticles on breast cancer using different 2D and 3D cell culture models. Int. J. Nanomed. 2019, 14, 161-180. [CrossRef] [PubMed]

54. Martinkova, P.; Brtnicky, M.; Kynicky, J.; Pohanka, M. Iron oxide nanoparticles: Innovative tool in cancer diagnosis and therapy. Adv. Healthc. Mater. 2018, 7, 1700932. [CrossRef] [PubMed]

55. Rego, G.N.A.; Mamani, J.B.; Souza, T.K.F.; Nucci, M.P.; Silva, H.R.D.; Gamarra, L.F. Therapeutic evaluation of magnetic hyperthermia using $\mathrm{Fe}_{3} \mathrm{O}_{4}$-aminosilane-coated iron oxide nanoparticles in glioblastoma animal model. Einstein (Sao Paulo Braz.) 2019, 17, eAO4786. [CrossRef] [PubMed]

56. Vangijzegem, T.; Stanicki, D.; Laurent, S. Magnetic iron oxide nanoparticles for drug delivery: Applications and characteristics. Expert Opin. Drug Deliv. 2019, 16, 69-78. [CrossRef]

57. Tian, X.; Zhu, M.; Nie, G. How can nanotechnology help membrane vesicle-based cancer immunotherapy development? Hum. Vaccin. Immunother. 2013, 9, 222-225. [CrossRef]

58. Antimisiaris, S.G.; Mourtas, S.; Marazioti, A. Exosomes and exosome-inspired vesicles for targeted drug delivery. Pharmaceutics 2018, 10, 218. [CrossRef] [PubMed]

59. Zhang, Z.; Dombroski, J.A.; King, M.R. Engineering of exosomes to target cancer metastasis. Cell. Mol. Bioeng. 2019, 13, 1-16. [CrossRef]

60. Parodi, A.; Miao, J.; Soond, S.M.; Rudzińska, M.; Zamyatnin, A.A., Jr. Albumin nanovectors in cancer therapy and imaging. Biomolecules 2019, 9, 218. [CrossRef]

61. Abraxane Package Insert. Available online: https://www.accessdata.fda.gov/drugsatfda_docs/label/2013/ 021660s037lbl.pdf (accessed on 28 January 2020).

62. Krishnamachari, Y.; Geary, S.M.; Lemke, C.D.; Salem, A.K. Nanoparticle delivery systems in cancer vaccines. Pharm. Res. 2011, 28, 215-236. [CrossRef]

63. Wiedermann, U.; Wiltschke, C.; Jasinska, J.; Kundi, M.; Zurbriggen, R.; Garner-Spitzer, E.; Bartsch, R.; Steger, G.; Pehamberger, H.; Scheiner, O.; et al. A virosomal formulated Her-2/neu multi-peptide vaccine induces Her-2/neu-specific immune responses in patients with metastatic breast cancer: A phase I study. Breast Cancer Res. Treat. 2010, 119, 673-683. [CrossRef]

64. Nam, L.; Coll, C.; Erthal, L.C.S.; de la Torre, C.; Serrano, D.; Martínez-Máñez, R.; Santos-Martínez, M.J.; Ruiz-Hernández, E. Drug delivery nanosystems for the localized treatment of glioblastoma multiforme. Materials 2018, 11, 779. [CrossRef] [PubMed]

65. Vallet-Regí, M.; Colilla, M.; Izquierdo-Barba, I.; Manzano, M. Mesoporous silica nanoparticles for drug delivery: Current insights. Molecules 2017, 23, 47. [CrossRef] [PubMed] 
66. Ilhan-Ayisigi, E.; Yesil-Celiktas, O. Silica-based organic-inorganic hybrid nanoparticles and nanoconjugates for improved anticancer drug delivery. Eng. Life Sci. 2018, 18, 882-892. [CrossRef] [PubMed]

67. Ortiz-Islas, E.; Manriquez-Ramirez, M.E.; Sosa-Munoz, A.; Almaguer, P.; Arias, C.; Guevara, P.; Hernandez-Cortez, G.; Aguirre-Cruz, M.L. Preparation and characterisation of silica-based nanoparticles for cisplatin release on cancer brain cells. IET Nanobiotechnol. 2020, 14, 191-197. [CrossRef] [PubMed]

68. Rahmani, S.; Budimir, J.; Sejalon, M.; Daurat, M.; Aggad, D.; Vivès, E.; Raehm, L.; Garcia, M.; Lichon, L.; Gary-Bobo, M.; et al. Large pore mesoporous silica and organosilica nanoparticles for pepstatin a delivery in breast cancer cells. Molecules 2019, 24, 332. [CrossRef]

69. Wang, D.; Li, X.; Li, X.; Kang, A.; Sun, L.; Sun, M.; Yang, F.; Xu, C. Magnetic and pH dual-responsive nanoparticles for synergistic drug-resistant breast cancer chemo/photodynamic therapy. Int. J. Nanomed. 2019, 14, 7665-7679. [CrossRef]

70. West, J.L.; Halas, N.J. Applications of nanotechnology to biotechnology commentary. Curr. Opin. Biotechnol. 2000, 11, 215-217. [CrossRef]

71. Kherlopian, A.R.; Song, T.; Duan, Q.; Neimark, M.A.; Po, M.J.; Gohagan, J.K.; Laine, A.F. A review of imaging techniques for systems biology. BMC Syst. Biol. 2008, 2, 74. [CrossRef]

72. Riley, R.S.; O'Sullivan, R.K.; Potocny, A.M.; Rosenthal, J.; Day, E.S. Evaluating nanoshells and a potent biladiene photosensitizer for dual photothermal and photodynamic therapy of triple negative breast cancer cells. Nanomaterials 2018, 8, 658. [CrossRef]

73. Klibanov, A.L. Microbubble contrast agents: Targeted ultrasound imaging and ultrasound-assisted drug-delivery applications. Invest. Radiol. 2006, 41, 354-362. [CrossRef]

74. Gao, Z.; Kennedy, A.M.; Christensen, D.A.; Rapoport, N.Y. Drug-loaded nano/microbubbles for combining ultrasonography and targeted chemotherapy. Ultrasonics 2008, 48, 260-270. [CrossRef] [PubMed]

75. Başpınar, Y.; Erel-Akbaba, G.; Kotmakçı, M.; Akbaba, H. Development and characterization of nanobubbles containing paclitaxel and survivin inhibitor YM155 against lung cancer. Int. J. Pharm. 2019, 566, 149-156. [CrossRef]

76. Kazi, K.M.; Mandal, A.S.; Biswas, N.; Guha, A.; Chatterjee, S.; Behera, M.; Kuotsu, K. Niosome: A future of targeted drug delivery systems. J. Adv. Pharm. Technol. Res. 2010, 1, 374-380. [PubMed]

77. Ag Seleci, D.; Seleci, M.; Walter, J.-G.; Stahl, F.; Scheper, T. Niosomes as nanoparticular drug carriers: Fundamentals and recent applications. J. Nanomater. 2016, 2016, 7372306. [CrossRef]

78. Madhav, N.; Saini, A. Niosomes: A novel drug delivery system. Int. J. Res. Pharm. Chem. 2011, 1, 498-511.

79. Patel, H.M.; Patel, B.B.; Shah, C.N. Nanosuspension: A novel approch to enhance solubility of poorly water soluble drugs-A review. Int. J. Adv. Pharm. 2016, 5, 21-29.

80. Yang, S.; Zhang, B.; Gong, X.; Wang, T.; Liu, Y.; Zhang, N. In vivo biodistribution, biocompatibility, and efficacy of sorafenib-loaded lipid-based nanosuspensions evaluated experimentally in cancer. Int. J. Nanomed. 2016, 11, 2329-2343.

81. Dong, D.; Hsiao, C.-H.; Giovanella, B.C.; Wang, Y.; Chow, D.S.; Li, Z. Sustained delivery of a camptothecin prodrug-CZ48 by nanosuspensions with improved pharmacokinetics and enhanced anticancer activity. Int. J. Nanomed. 2019, 14, 3799-3817. [CrossRef]

82. Huang, T.; Wang, Y.; Shen, Y.; Ao, H.; Guo, Y.; Han, M.; Wang, X. Preparation of high drug-loading celastrol nanosuspensions and their anti-breast cancer activities in vitro and in vivo. Sci. Rep. 2020, 10, 8851. [CrossRef]

83. Berkner, S.; Schwirn, K.; Voelker, D. Nanopharmaceuticals: Tiny challenges for the environmental risk assessment of pharmaceuticals. Environ. Toxicol. Chem. 2016, 35, 780-787. [CrossRef]

84. Patra, J.K.; Das, G.; Fraceto, L.F.; Campos, E.V.R.; Rodriguez-Torres, M.D.P.; Acosta-Torres, L.S.; Diaz-Torres, L.A.; Grillo, R.; Swamy, M.K.; Sharma, S.; et al. Nano based drug delivery systems: Recent developments and future prospects. J. Nanobiotechnology 2018, 16, 71. [CrossRef]

85. Li, W.; Yalcin, M.; Bharali, D.J.; Lin, Q.; Godugu, K.; Fujioka, K.; Keating, K.A.; Mousa, S.A. Pharmacokinetics, biodistribution, and anti-angiogenesis efficacy of diamino propane tetraiodothyroacetic acid-conjugated biodegradable polymeric nanoparticle. Sci. Rep. 2019, 9, 9006. [CrossRef] [PubMed]

86. Flores, O.; Santra, S.; Kaittanis, C.; Bassiouni, R.; Khaled, A.S.; Khaled, A.R.; Grimm, J.; Perez, J.M. PSMA-targeted theranostic nanocarrier for prostate cancer. Theranostics 2017, 7, 2477-2494. [CrossRef] 
87. Darwish, N.H.E.; Sudha, T.; Godugu, K.; Bharali, D.J.; Elbaz, O.; El-Ghaffar, H.A.A.; Azmy, E.; Anber, N.; Mousa, S.A. Novel targeted nano-parthenolide molecule against NF-kB in acute myeloid leukemia. Molecules 2019, 24, 2103. [CrossRef] [PubMed]

88. Bharali, D.J.; Sudha, T.; Cui, H.; Mian, B.M.; Mousa, S.A. Anti-CD24 nano-targeted delivery of docetaxel for the treatment of prostate cancer. Nanomedicine 2017, 13, 263-273. [CrossRef] [PubMed]

89. Sudha, T.; Bharali, D.J.; Yalcin, M.; Darwish, N.H.; Debreli Coskun, M.; Keating, K.A.; Lin, H.Y.; Davis, P.J.; Mousa, S.A. Targeted delivery of paclitaxel and doxorubicin to cancer xenografts via the nanoparticle of nano-diamino-tetrac. Int. J. Nanomed. 2017, 12, 1305-1315. [CrossRef]

90. Sudha, T.; Bharali, D.J.; Yalcin, M.; Darwish, N.H.; Coskun, M.D.; Keating, K.A.; Lin, H.Y.; Davis, P.J.; Mousa, S.A. Targeted delivery of cisplatin to tumor xenografts via the nanoparticle component of nano-diamino-tetrac. Nanomedicine (Lond) 2017, 12, 195-205. [CrossRef]

91. Hariri, W.; Sudha, T.; Bharali, D.J.; Cui, H.; Mousa, S.A. Nano-targeted delivery of toremifene, an estrogen receptor- $\alpha$ blocker in prostate cancer. Pharm. Res. 2015, 32, 2764-2774. [CrossRef]

92. Jampilek, J.; Kos, J.; Kralova, K. Potential of nanomaterial applications in dietary supplements and foods for special medical purposes. Nanomaterials 2019, 9, 296. [CrossRef]

93. Wiwanitkit, V. Delivery of nutraceuticals using nanotechnology. Agro Food Ind. Hi Tech. 2013, $24,218$. [CrossRef]

94. Dillard, C.J.; German, J.B. Phytochemicals: Nutraceuticals and human health. J. Sci. Food Agric. 2000, 80, 1744-1756. [CrossRef]

95. Chikara, S.; Nagaprashantha, L.D.; Singhal, J.; Horne, D.; Awasthi, S.; Singhal, S.S. Oxidative stress and dietary phytochemicals: Role in cancer chemoprevention and treatment. Cancer Lett. 2018, 413, 122-134. [CrossRef]

96. Dandawate, P.R.; Subramaniam, D.; Jensen, R.A.; Anant, S. Targeting cancer stem cells and signaling pathways by phytochemicals: Novel approach for breast cancer therapy. Semin. Cancer Biol. 2016, 40-41, 192-208. [CrossRef]

97. Biersack, B.; Schobert, R. Indole compounds against breast cancer: Recent developments. Curr. Drug Targets 2012, 13, 1705-1719. [CrossRef]

98. Clark, R.; Lee, S.H. Anticancer properties of capsaicin against human cancer. Anticancer Res. 2016, 36, 837-843.

99. Lidia, A.-V.; Carlos, Z.-M.; Alicia, R.-M.; Amalia, V.-V.; José, V.-B. Nutraceuticals: Definition, applied nanoengineering in their production and applications. Int. J. Biosen. Bioelectron. 2019, 5, 56-61. [CrossRef]

100. Jeong, S.Y.; Park, S.J.; Yoon, S.M.; Jung, J.; Woo, H.N.; Yi, S.L.; Song, S.Y.; Park, H.J.; Kim, C.; Lee, J.S.; et al. Systemic delivery and preclinical evaluation of Au nanoparticle containing beta-lapachone for radiosensitization. J. Control. Release 2009, 139, 239-245. [CrossRef]

101. Blanco, E.; Bey, E.A.; Dong, Y.; Weinberg, B.D.; Sutton, D.M.; Boothman, D.A.; Gao, J. Beta-lapachonecontaining PEG-PLA polymer micelles as novel nanotherapeutics against NQO1-overexpressing tumor cells. J. Control. Release 2007, 122, 365-374. [CrossRef]

102. Yang, Y.; Zhou, X.; Xu, M.; Piao, J.; Zhang, Y.; Lin, Z.; Chen, L. B-lapachone suppresses tumour progression by inhibiting epithelial-to-mesenchymal transition in NQO1-positive breast cancers. Sci. Rep. 2017, 7, 2681. [CrossRef]

103. Ma, X.; Moore, Z.R.; Huang, G.; Huang, X.; Boothman, D.A.; Gao, J. Nanotechnology-enabled delivery of NQO1 bioactivatable drugs. J. Drug Target. 2015, 23, 672-680. [CrossRef]

104. Tsai, Y.M.; Chien, C.F.; Lin, L.C.; Tsai, T.H. Curcumin and its nano-formulation: The kinetics of tissue distribution and blood-brain barrier penetration. Int. J. Pharm. 2011, 416, 331-338. [CrossRef]

105. Marjaneh, R.M.; Rahmani, F.; Hassanian, S.M.; Rezaei, N.; Hashemzehi, M.; Bahrami, A.; Ariakia, F.; Fiuji, H.; Sahebkar, A.; Avan, A.; et al. Phytosomal curcumin inhibits tumor growth in colitis-associated colorectal cancer. J. Cell. Physiol. 2018, 233, 6785-6798. [CrossRef]

106. Prabhuraj, R.S.; Bomb, K.; Srivastava, R.; Bandyopadhyaya, R. Dual drug delivery of curcumin and niclosamide using PLGA nanoparticles for improved therapeutic effect on breast cancer cells. J. Polymer Res. 2020, 27, 133.

107. Mukerjee, A.; Vishwanatha, J.K. Formulation, characterization and evaluation of curcumin-loaded PLGA nanospheres for cancer therapy. Anticancer Res. 2009, 29, 3867-3875. 
108. Punfa, W.; Yodkeeree, S.; Pitchakarn, P.; Ampasavate, C.; Limtrakul, P. Enhancement of cellular uptake and cytotoxicity of curcumin-loaded PLGA nanoparticles by conjugation with anti-p-glycoprotein in drug resistance cancer cells. Acta Pharmacol. Sin. 2012, 33, 823-831. [CrossRef]

109. Das, R.K.; Kasoju, N.; Bora, U. Encapsulation of curcumin in alginate-chitosan-pluronic composite nanoparticles for delivery to cancer cells. Nanomedicine 2010, 6, 153-160. [CrossRef]

110. Sahu, A.; Kasoju, N.; Bora, U. Fluorescence study of the curcumin-casein micelle complexation and its application as a drug nanocarrier to cancer cells. Biomacromolecules 2008, 9, 2905-2912. [CrossRef]

111. Bisht, S.; Feldmann, G.; Soni, S.; Ravi, R.; Karikar, C.; Maitra, A.; Maitra, A. Polymeric nanoparticleencapsulated curcumin ("nanocurcumin"): A novel strategy for human cancer therapy. J. Nanobiotechnology 2007, 5, 3. [CrossRef] [PubMed]

112. Mulik, R.S.; Monkkonen, J.; Juvonen, R.O.; Mahadik, K.R.; Paradkar, A.R. Transferrin mediated solid lipid nanoparticles containing curcumin: Enhanced in vitro anticancer activity by induction of apoptosis. Int. J. Pharm. 2010, 398, 190-203. [CrossRef] [PubMed]

113. He, Y.; Liu, H.; Bian, W.; Liu, Y.; Liu, X.; Ma, S.; Zheng, X.; Du, Z.; Zhang, K.; Ouyang, D. Molecular interactions for the curcumin-polymer complex with enhanced anti-inflammatory effects. Pharmaceutics 2019, 11, 442. [CrossRef]

114. Soto-Quintero, A.; Guarrotxena, N.; García, O.; Quijada-Garrido, I. Curcumin to promote the synthesis of silver nps and their self-assembly with a thermoresponsive polymer in core-shell nanohybrids. Sci. Rep. 2019, 9, 18187. [CrossRef] [PubMed]

115. Gao, Y.; Gu, W.; Chen, L.; Xu, Z.; Li, Y. The role of daidzein-loaded sterically stabilized solid lipid nanoparticles in therapy for cardio-cerebrovascular diseases. Biomaterials 2008, 29, 4129-4136. [CrossRef] [PubMed]

116. Jin, S.; Zhang, Q.Y.; Kang, X.M.; Wang, J.X.; Zhao, W.H. Daidzein induces MCF-7 breast cancer cell apoptosis via the mitochondrial pathway. Ann. Oncol. 2010, 21, 263-268. [CrossRef] [PubMed]

117. Contreras, J.; Xie, J.; Chen, Y.J.; Pei, H.; Zhang, G.; Fraser, C.L.; Hamm-Alvarez, S.F. Intracellular uptake and trafficking of difluoroboron dibenzoylmethane-polylactide nanoparticles in HeLa cells. ACS Nano 2010, 4, 2735-2747. [CrossRef] [PubMed]

118. Almelah, E.; Smith, D.P.; McGown, A.; Aziz, A.; Potgieter, H.J.; Ragazzon, P. Dibenzoyl-methane derivatives as a potential and exciting new therapy for the treatment of childhood bone cancer. Anticancer Res. 2016, 36, 6043-6050. [CrossRef]

119. Khor, T.O.; Yu, S.; Barve, A.; Hao, X.; Hong, J.L.; Lin, W.; Foster, B.; Huang, M.T.; Newmark, H.L.; Kong, A.N. Dietary feeding of dibenzoylmethane inhibits prostate cancer in transgenic adenocarcinoma of the mouse prostate model. Cancer Res. 2009, 69, 7096-7102. [CrossRef]

120. Guo, S.; Yao, X.; Jiang, Q.; Wang, K.; Zhang, Y.; Peng, H.; Tang, J.; Yang, W. Dihydroartemisinin-loaded magnetic nanoparticles for enhanced chemodynamic therapy. Front. Pharmacol. 2020, 11, 226. [CrossRef] [PubMed]

121. Li, X.; Ba, Q.; Liu, Y.; Yue, Q.; Chen, P.; Li, J.; Zhang, H.; Ying, H.; Ding, Q.; Song, H.; et al. Dihydroartemisinin selectively inhibits PDGFR $\alpha$-positive ovarian cancer growth and metastasis through inducing degradation of PDGFR $\alpha$ protein. Cell Discov. 2017, 3, 17042. [CrossRef] [PubMed]

122. Jiang, C.; Li, S.; Li, Y.; Bai, Y. Anticancer effects of dihydroartemisinin on human esophageal cancer cells in vivo. Anal. Cell. Pathol. 2018, 2018, 8759745. [CrossRef]

123. Ali, O.M.; Bekhit, A.A.; Khattab, S.N.; Helmy, M.W.; Abdel-Ghany, Y.S.; Teleb, M.; Elzoghby, A.O. Synthesis of lactoferrin mesoporous silica nanoparticles for pemetrexed/ellagic acid synergistic breast cancer therapy. Colloids Surf. B Biointerfaces 2020, 188, 110824. [CrossRef]

124. Ceci, C.; Lacal, P.M.; Tentori, L.; De Martino, M.G.; Miano, R.; Graziani, G. Experimental evidence of the antitumor, antimetastatic and antiangiogenic activity of ellagic acid. Nutrients 2018, 10, 1756. [CrossRef] [PubMed]

125. Neamatallah, T.; El-Shitany, N.; Abbas, A.; Eid, B.G.; Harakeh, S.; Ali, S.; Mousa, S. Nano ellagic acid counteracts cisplatin-induced upregulation in OAT1 and OAT3: A possible nephroprotection mechanism. Molecules 2020, 25, 3031. [CrossRef]

126. Khan, N.; Bharali, D.J.; Adhami, V.M.; Siddiqui, I.A.; Cui, H.; Shabana, S.M.; Mousa, S.A.; Mukhtar, H. Oral administration of naturally occurring chitosan-based nanoformulated green tea polyphenol EGCG effectively inhibits prostate cancer cell growth in a xenograft model. Carcinogenesis 2014, 35, 415-423. [CrossRef] [PubMed] 
127. Zeng, L.; Yan, J.; Luo, L.; Ma, M.; Zhu, H. Preparation and characterization of (-)-epigallocatechin-3-gallate (EGCG)-loaded nanoparticles and their inhibitory effects on human breast cancer MCF-7 cells. Sci. Rep. 2017, 7, 45521. [CrossRef]

128. Granja, A.; Frias, I.; Neves, A.R.; Pinheiro, M.; Reis, S. Therapeutic potential of epigallocatechin gallate nanodelivery systems. Biomed. Res. Int. 2017, 2017, 5813793. [CrossRef]

129. Majeed, H.; Antoniou, J.; Fang, Z. Apoptotic effects of eugenol-loaded nanoemulsions in human colon and liver cancer cell lines. Asian Pac. J. Cancer Prev. 2014, 15, 9159-9164. [CrossRef]

130. Abdullah, M.L.; Hafez, M.M.; Al-Hoshani, A.; Al-Shabanah, O. Anti-metastatic and anti-proliferative activity of eugenol against triple negative and HER2 positive breast cancer cells. BMC Complement. Altern. Med. 2018, 18, 321. [CrossRef]

131. Shahabadi, N.; Akbari, A.; Karampour, F.; Falsafi, M. Cytotoxicity and antibacterial activities of new chemically synthesized magnetic nanoparticles containing eugenol. J. Drug Deliv. Sci. Technol. 2019, 49, 113-122. [CrossRef]

132. Zheng, Y.; You, X.; Guan, S.; Huang, J.; Wang, L.; Zhang, J.; Wu, J. Poly(ferulic acid) with an anticancer effect as a drug nanocarrier for enhanced colon cancer therapy. Adv. Funct. Mater. 2019, 29, 1808646. [CrossRef]

133. Thakkar, A.; Chenreddy, S.; Wang, J.; Prabhu, S. Ferulic acid combined with aspirin demonstrates chemopreventive potential towards pancreatic cancer when delivered using chitosan-coated solid-lipid nanoparticles. Cell Biosci. 2015, 5, 46. [CrossRef]

134. Saeed, L.M.; Mahmood, M.; Pyrek, S.J.; Fahmi, T.; Xu, Y.; Mustafa, T.; Nima, Z.A.; Bratton, S.M.; Casciano, D.; Dervishi, E.; et al. Single-walled carbon nanotube and graphene nanodelivery of gambogic acid increases its cytotoxicity in breast and pancreatic cancer cells. J. Appl. Toxicol. 2014, 34, 1188-1199. [CrossRef]

135. Wang, P.; Jiang, F.; Chen, B.; Tang, H.; Zeng, X.; Cai, D.; Zhu, M.; Long, R.; Yang, D.; Kankala, R.K.; et al. Bioinspired red blood cell membrane-encapsulated biomimetic nanoconstructs for synergistic and efficacious chemo-photothermal therapy. Colloids Surf. B Biointerfaces 2020, 189, 110842. [CrossRef] [PubMed]

136. Pool, H.; Campos-Vega, R.; Herrera-Hernández, M.G.; García-Solis, P.; García-Gasca, T.; Sánchez, I.C.; Luna-Bárcenas, G.; Vergara-Castañeda, H. Development of genistein-pegylated silica hybrid nanomaterials with enhanced antioxidant and antiproliferative properties on HT29 human colon cancer cells. Am. J. Transl. Res. 2018, 10, 2306-2323. [PubMed]

137. Zhang, H.; Liu, G.; Zeng, X.; Wu, Y.; Yang, C.; Mei, L.; Wang, Z.; Huang, L. Fabrication of genistein-loaded biodegradable TPGS-b-PCL nanoparticles for improved therapeutic effects in cervical cancer cells. Int. J. Nanomed. 2015, 10, 2461-2473.

138. Tang, P.; Sun, Q.; Yang, H.; Tang, B.; Pu, H.; Li, H. Honokiol nanoparticles based on epigallocatechin gallate functionalized chitin to enhance therapeutic effects against liver cancer. Int. J. Pharm. 2018, 545, 74-83. [CrossRef]

139. AbdElhamid, A.S.; Zayed, D.G.; Helmy, M.W.; Ebrahim, S.M.; Bahey-El-Din, M.; Zein-El-Dein, E.A.; El-Gizawy, S.A.; Elzoghby, A.O. Lactoferrin-tagged quantum dots-based theranostic nanocapsules for combined cox-2 inhibitor/herbal therapy of breast cancer. Nanomedicine 2018, 13, 2637-2656. [CrossRef]

140. Ponnurangam, S.; Mammen, J.M.; Ramalingam, S.; He, Z.; Zhang, Y.; Umar, S.; Subramaniam, D.; Anant, S. Honokiol in combination with radiation targets notch signaling to inhibit colon cancer stem cells. Mol. Cancer Ther. 2012, 11, 963-972. [CrossRef] [PubMed]

141. Gao, D.Q.; Qian, S.; Ju, T. Anticancer activity of honokiol against lymphoid malignant cells via activation of ROS-jnk and attenuation of Nrf2 and NF-kappaB. J. BUON 2016, 21, 673-679. [PubMed]

142. Kaushik, G.; Kwatra, D.; Subramaniam, D.; Jensen, R.A.; Anant, S.; Mammen, J.M. Honokiol affects melanoma cell growth by targeting the AMP-activated protein kinase signaling pathway. Am. J. Surg. 2014, 208, 995-1002. [CrossRef]

143. Lu, C.H.; Chen, S.H.; Chang, Y.S.; Liu, Y.W.; Wu, J.Y.; Lim, Y.P.; Yu, H.I.; Lee, Y.R. Honokiol, a potential therapeutic agent, induces cell cycle arrest and program cell death in vitro and in vivo in human thyroid cancer cells. Pharmacol. Res. 2017, 115, 288-298. [CrossRef]

144. Lin, C.J.; Chen, T.L.; Tseng, Y.Y.; Wu, G.J.; Hsieh, M.H.; Lin, Y.W.; Chen, R.M. Honokiol induces autophagic cell death in malignant glioma through reactive oxygen species-mediated regulation of the p53/PI3K/Akt/mTOR signaling pathway. Toxicol. Appl. Pharmacol. 2016, 304, 59-69. [CrossRef]

145. Fuster, M.G.; Carissimi, G.; Montalbán, M.G.; Víllora, G. Improving anticancer therapy with naringeninloaded silk fibroin nanoparticles. Nanomaterials 2020, 10, 718. [CrossRef] 
146. Morais, R.P.; Novais, G.B.; Sangenito, L.S.; Santos, A.L.S.; Priefer, R.; Morsink, M.; Mendonça, M.C.; Souto, E.B.; Severino, P.; Cardoso, J.C. Naringenin-functionalized multi-walled carbon nanotubes: A potential approach for site-specific remote-controlled anticancer delivery for the treatment of lung cancer cells. Int. J. Mol. Sci. 2020, 21, 4557. [CrossRef] [PubMed]

147. Akhter, M.H.; Kumar, S.; Nomani, S. Sonication tailored enhance cytotoxicity of naringenin nanoparticle in pancreatic cancer: Design, optimization, and in vitro studies. Drug Dev. Ind. Pharm. 2020, 46, 659-672. [CrossRef] [PubMed]

148. Goh, J.X.H.; Tan, L.T.-H.; Goh, J.K.; Chan, K.G.; Pusparajah, P.; Lee, L.-H.; Goh, B.-H. Nobiletin and derivatives: Functional compounds from citrus fruit peel for colon cancer chemoprevention. Cancers 2019, 11, 867. [CrossRef] [PubMed]

149. Ashrafizadeh, M.; Zarrabi, A.; Saberifar, S.; Hashemi, F.; Hushmandi, K.; Hashemi, F.; Moghadam, E.R.; Mohammadinejad, R.; Najafi, M.; Garg, M. Nobiletin in cancer therapy: How this plant derived-natural compound targets various oncogene and onco-suppressor pathways. Biomedicines 2020, 8, 110. [CrossRef]

150. Liao, W.; Liu, Z.; Zhang, T.; Sun, S.; Ye, J.; Li, Z.; Mao, L.; Ren, J. Enhancement of anti-inflammatory properties of nobiletin in macrophages by a nano-emulsion preparation. J. Agric. Food Chem. 2018, 66, 91-98. [CrossRef] [PubMed]

151. Niazvand, F.; Orazizadeh, M.; Khorsandi, L.; Abbaspour, M.; Mansouri, E.; Khodadadi, A. Effects of quercetin-loaded nanoparticles on MCF-7 human breast cancer cells. Medicina 2019, 55, 114. [CrossRef] [PubMed]

152. Vafadar, A.; Shabaninejad, Z.; Movahedpour, A.; Fallahi, F.; Taghavipour, M.; Ghasemi, Y.; Akbari, M.; Shafiee, A.; Hajighadimi, S.; Moradizarmehri, S.; et al. Quercetin and cancer: New insights into its therapeutic effects on ovarian cancer cells. Cell Biosci. 2020, 10, 32. [CrossRef] [PubMed]

153. Tiwari, H.; Karki, N.; Pal, M.; Basak, S.; Verma, R.K.; Bal, R.; Kandpal, N.D.; Bisht, G.; Sahoo, N.G. Functionalized graphene oxide as a nanocarrier for dual drug delivery applications: The synergistic effect of quercetin and gefitinib against ovarian cancer cells. Colloids Surf. B Biointerfaces 2019, 178, 452-459. [CrossRef] [PubMed]

154. Ren, K.W.; Li, Y.H.; Wu, G.; Ren, J.Z.; Lu, H.B.; Li, Z.M.; Han, X.W. Quercetin nanoparticles display antitumor activity via proliferation inhibition and apoptosis induction in liver cancer cells. Int. J. Oncol. 2017, 50, 1299-1311. [CrossRef] [PubMed]

155. Li, H.; Zhao, X.; Ma, Y.; Zhai, G.; Li, L.; Lou, H. Enhancement of gastrointestinal absorption of quercetin by solid lipid nanoparticles. J. Control. Release 2009, 133, 238-244. [CrossRef] [PubMed]

156. Thipe, V.C.; Panjtan Amiri, K.; Bloebaum, P.; Raphael Karikachery, A.; Khoobchandani, M.; Katti, K.K.; Jurisson, S.S.; Katti, K.V. Development of resveratrol-conjugated gold nanoparticles: Interrelationship of increased resveratrol corona on anti-tumor efficacy against breast, pancreatic and prostate cancers. Int. J. Nanomed. 2019, 14, 4413-4428. [CrossRef] [PubMed]

157. Teskac, K.; Kristl, J. The evidence for solid lipid nanoparticles mediated cell uptake of resveratrol. Int. J. Pharm. 2010, 390, 61-69. [CrossRef]

158. Shahein, S.A.; Aboul-Enein, A.M.; Higazy, I.M.; Abou-Elella, F.; Lojkowski, W.; Ahmed, E.R.; Mousa, S.A.; AbouAitah, K. Targeted anticancer potential against glioma cells of thymoquinone delivered by mesoporous silica core-shell nanoformulations with pH-dependent release. Int. J. Nanomed. 2019, 14, 5503-5526. [CrossRef]

159. Shaarani, S.; Hamid, S.S.; Mohd Kaus, N.H. The influence of pluronic F68 and F127 nanocarrier on physicochemical properties, in vitro release, and antiproliferative activity of thymoquinone drug. Pharmacogn. Res. 2017, 9, 12-20.

160. Alam, S.; Khan, Z.I.; Mustafa, G.; Kumar, M.; Islam, F.; Bhatnagar, A.; Ahmad, F.J. Development and evaluation of thymoquinone-encapsulated chitosan nanoparticles for nose-to-brain targeting: A pharmacoscintigraphic study. Int. J. Nanomed. 2012, 7, 5705-5718. [CrossRef]

161. Zheng, W.; Wang, C.; Ding, R.; Huang, Y.; Li, Y.; Lu, Y. Triptolide-loaded nanoparticles targeting breast cancer in vivo with reduced toxicity. Int. J. Pharm. 2019, 572, 118721. [CrossRef]

162. Wang, Y.; Liu, X.; Wang, X.; Zheng, W.; Zhang, J.; Shi, F.; Liu, J. Redox-responsive self-assembly PEG nanoparticle enhanced triptolide for efficient antitumor treatment. Sci. Rep. 2018, 8, 12968. [CrossRef]

163. Wang, C.; Liu, B.; Xu, X.; Zhuang, B.; Li, H.; Yin, J.; Cong, M.; Xu, W.; Lu, A. Toward targeted therapy in chemotherapy-resistant pancreatic cancer with a smart triptolide nanomedicine. Oncotarget 2016, 7, 8360-8372. [CrossRef] 
164. Razak, S.; Afsar, T.; Ullah, A.; Almajwal, A.; Alkholief, M.; Alshamsan, A.; Jahan, S. Taxifolin, a natural flavonoid interacts with cell cycle regulators causes cell cycle arrest and causes tumor regression by activating Wnt/ $\beta$-catenin signaling pathway. BMC Cancer 2018, 18, 1043. [CrossRef] [PubMed]

165. Sundraraman, G.; Jayakumari, L.S. Meticulous taxifolin releasing performance by the zinc oxide nanoparticles: As a short road to drug delivery system for cancer therapeutics. J. Cluster Sci. 2020, 31, 241-255. [CrossRef]

166. Watkins, R.; Wu, L.; Zhang, C.; Davis, R.M.; Xu, B. Natural product-based nanomedicine: Recent advances and issues. Int. J. Nanomed. 2015, 10, 6055-6074.

167. Wang, S.; Meng, X.; Dong, Y. Ursolic acid nanoparticles inhibit cervical cancer growth in vitro and in vivo via apoptosis induction. Int. J. Oncol. 2017, 50, 1330-1340. [CrossRef]

168. Luo, J.; Hu, Y.L.; Wang, H. Ursolic acid inhibits breast cancer growth by inhibiting proliferation, inducing autophagy and apoptosis, and suppressing inflammatory responses via the PI3K/AKT and NF-кB signaling pathways in vitro. Exp. Ther. Med. 2017, 14, 3623-3631. [CrossRef]

169. Li, T.; Chen, X.; Liu, Y.; Fan, L.; Lin, L.; Xu, Y.; Chen, S.; Shao, J. pH-sensitive mesoporous silica nanoparticles anticancer prodrugs for sustained release of ursolic acid and the enhanced anti-cancer efficacy for hepatocellular carcinoma cancer. Eur. J. Pharm. Sci. 2017, 96, 456-463. [CrossRef]

170. Shao, J.; Fang, Y.; Zhao, R.; Chen, F.; Yang, M.; Jiang, J.; Chen, Z.; Yuan, X.; Jia, L. Evolution from small molecule to nano-drug delivery systems: An emerging approach for cancer therapy of ursolic acid. Asian J. Pharm. Sci. 2020. [CrossRef]

171. Caldeira de Araujo Lopes, S.; Vinicius Melo Novais, M.; Salviano Teixeira, C.; Honorato-Sampaio, K.; Tadeu Pereira, M.; Ferreira, L.A.; Braga, F.C.; Cristina Oliveira, M. Preparation, physicochemical characterization, and cell viability evaluation of long-circulating and $\mathrm{pH}$-sensitive liposomes containing ursolic acid. Biomed. Res. Int. 2013, 2013, 467147. [CrossRef]

172. Zhao, T.; Liu, Y.; Gao, Z.; Gao, D.; Li, N.; Bian, Y.; Dai, K.; Liu, Z. Self-assembly and cytotoxicity study of PEG-modified ursolic acid liposomes. Mater. Sci. Eng. C 2015, 53, 196-203. [CrossRef]

173. Jin, H.; Pi, J.; Yang, F.; Wu, C.; Cheng, X.; Bai, H.; Huang, D.; Jiang, J.; Cai, J.; Chen, Z.W. Ursolic acid-loaded chitosan nanoparticles induce potent anti-angiogenesis in tumor. Appl. Microbiol. Biotechnol. 2016, 100, 6643-6652. [CrossRef]

174. Godugu, K.; El-Far, A.H.; Al Jaouni, S.; Mousa, S.A. Nanoformulated Ajwa (Phoenix Dactylifera) bioactive compounds improve the safety of doxorubicin without compromising its anticancer efficacy in breast cancer. Molecules 2020, 25, 2597. [CrossRef] [PubMed]

175. Loutfy, S.A.; Elberry, M.H.; Farroh, K.Y.; Mohamed, H.T.; Mohamed, A.A.; Mohamed, E.B.; Faraag, A.H.I.; Mousa, S.A. Antiviral activity of chitosan nanoparticles encapsulating curcumin against hepatitis c virus genotype 4a in human hepatoma cell lines. Int. J. Nanomed. 2020, 15, 2699-2715. [CrossRef] [PubMed]

176. Salaheldin, T.A.; Bharali, D.J.; Mousa, S.A. Functionalized nano-targeted moieties in management of prostate cancer. Future Oncol. 2020, 16, 869-883. [CrossRef]

177. Mousa, D.S.; El-Far, A.H.; Saddiq, A.A.; Sudha, T.; Mousa, S.A. Nanoformulated bioactive compounds derived from different natural products combat pancreatic cancer cell proliferation. Int. J. Nanomed. 2020, 15, 2259-2268. [CrossRef] [PubMed]

178. Sudha, T.; El-Far, A.H.; Mousa, D.S.; Mousa, S.A. Resveratrol and its nanoformulation attenuate growth and the angiogenesis of xenograft and orthotopic colon cancer models. Molecules 2020, 25, 1412. [CrossRef] [PubMed]

179. Wolfram, J.; Ferrari, M. Clinical cancer nanomedicine. Nano Today 2019, 25, 85-98. [CrossRef] [PubMed]

180. Zhang, Y.; Li, M.; Gao, X.; Chen, Y.; Liu, T. Nanotechnology in cancer diagnosis: Progress, challenges and opportunities. J. Hematol. Oncol. 2019, 12, 137. [CrossRef]

181. A First in Human Study Using 89Zr-cRGDY Ultrasmall Silica Particle Tracers for Malignant Brain Tumors. Available online: https://clinicaltrials.gov/ct2/show/NCT03465618 (accessed on 31 July 2020).

182. Carbon Nanoparticles as Lymph Node Tracer in Rectal Cancer after Neoadjuvant Radiochemotherapy (CALOR-NAT). Available online: https://clinicaltrials.gov/ct2/show/NCT03550001 (accessed on 31 July 2020).

183. Ferumoxytol-Iron Oxide Nanoparticle Magnetic Resonance Dynamic Contrast Enhanced MRI. Available online: https://clinicaltrials.gov/ct2/show/NCT01895829 (accessed on 31 July 2020).

184. Diagnosis of Gastric Lesions with Na-Nose. Available online: https:/www.centerwatch.com/clinical-trials/ listings/162656/stomach-diseases-diagnosis-gastric-lesions-na-nose/ (accessed on 31 July 2020). 
185. Nanochip Technology in Monitoring Treatment Response and Detecting Relapse in Participants with Diffuse Large B-Cell Lymphoma. Available online: https:/clinicaltrials.gov/ct2/show/NCT03656835 (accessed on 31 July 2020).

186. Bosetti, R.; Jones, S.L. Cost-effectiveness of nanomedicine: Estimating the real size of nano-costs. Nanomedicine (Lond) 2019, 14, 1367-1370. [CrossRef]

187. Grodzinski, P.; Kircher, M.; Goldberg, M.; Gabizon, A. Integrating nanotechnology into cancer care. ACS Nano 2019, 13, 7370-7376. [CrossRef]

188. Navya, P.N.; Kaphle, A.; Srinivas, S.P.; Bhargava, S.K.; Rotello, V.M.; Daima, H.K. Current trends and challenges in cancer management and therapy using designer nanomaterials. Nano Converg. 2019, 6, 23. [CrossRef]

189. Lin, Y.W.; Huang, C.C.; Chang, H.T. Gold nanoparticle probes for the detection of mercury, lead and copper ions. Analyst 2011, 136, 863-871. [CrossRef]

190. Autio, K.A.; Dreicer, R.; Anderson, J.; Garcia, J.A.; Alva, A.; Hart, L.L.; Milowsky, M.I.; Posadas, E.M.; Ryan, C.J.; Graf, R.P.; et al. Safety and efficacy of BIND-014, a docetaxel nanoparticle targeting prostate-specific membrane antigen for patients with metastatic castration-resistant prostate cancer: A phase 2 clinical trial. JAMA Oncol. 2018, 4, 1344-1351. [CrossRef] [PubMed]

191. He, H.; Liu, L.; Morin, E.E.; Liu, M.; Schwendeman, A. Survey of clinical translation of cancer nanomedicines-lessons learned from successes and failures. Acc. Chem. Res. 2019, 52, 2445-2461. [CrossRef] [PubMed]

192. Paradise, J. Regulating nanomedicine at the Food and Drug Administration. AMA J. Ethics 2019, 21, E347-E355.

193. U.S. Food \& Drug Administration. FDA's approach to regulation of nanotechnology products. Available online: https://www.fda.gov/science-research/nanotechnology-programs-fda/fdas-approachregulation-nanotechnology-products (accessed on 31 July 2020).

194. Park, K. The beginning of the end of the nanomedicine hype. J. Control. Release 2019, 305, 221-222. [CrossRef]

195. Tran, S.; DeGiovanni, P.J.; Piel, B.; Rai, P. Cancer nanomedicine: A review of recent success in drug delivery. Clin. Trans. Med. 2017, 6, 44. [CrossRef] [PubMed]

196. Van der Meel, R.; Lammers, T.; Hennink, W.E. Cancer nanomedicines: Oversold or underappreciated? Expert Opin. Drug Deliv. 2017, 14, 1-5. [CrossRef]

197. Maeda, H. Toward a full understanding of the EPR effect in primary and metastatic tumors as well as issues related to its heterogeneity. Adv. Drug Deliv. Rev. 2015, 91, 3-6. [CrossRef] [PubMed]

198. Bae, Y.H.; Park, K. Targeted drug delivery to tumors: Myths, reality and possibility. J. Control. Release 2011, 153, 198-205. [CrossRef]

199. Anselmo, A.C.; Mitragotri, S. Nanoparticles in the clinic: An update. Bioeng. Transl. Med. 2019, 4, e10143. [CrossRef]

(C) 2020 by the authors. Licensee MDPI, Basel, Switzerland. This article is an open access article distributed under the terms and conditions of the Creative Commons Attribution (CC BY) license (http://creativecommons.org/licenses/by/4.0/). 